Article

\title{
Impact of Water and Land Resources Matching on Agricultural Sustainable Economic Growth: Empirical Analysis with Spatial Spillover Effects from Yellow River Basin, China
}

\author{
Yujiao Zhou ${ }^{1}\left(\mathbb{D}\right.$, Weifeng $\mathrm{Li}^{2, *}$, Huihui Li ${ }^{3}$, Zhen Wang ${ }^{4}$, Bei Zhang ${ }^{5}$ and Kaiyang Zhong ${ }^{6, *(\mathbb{D})}$ \\ 1 School of Economics, Southwestern University of Finance and Economics, Chengdu 611130, China; \\ zhouyujiao2015@163.com \\ 2 PBC School of Finance, Tsinghua University, Beijing 100084, China \\ 3 Guangdong Rural Credit Union, Guangzhou 510627, China; lhhgdrcu@163.com \\ 4 School of Business Administration, Southwestern University of Finance and Economics, \\ Chengdu 611170, China; 117020298002@smail.swufe.edu.cn \\ 5 College of Economics \& Management, Beijing University of Technology, Beijing 100124, China; \\ 13990145342@163.com \\ 6 School of Economic Information Engineering, Southwestern University of Finance and Economics, \\ Chengdu 611130, China \\ * Correspondence: liwf@pbcsf.tsinghua.edu.cn (W.L.); zhongky@smail.swufe.edu.cn (K.Z.)
}

check for

updates

Citation: Zhou, Y.; Li, W.; Li, H.;

Wang, Z.; Zhang, B.; Zhong, K.

Impact of Water and Land Resources

Matching on Agricultural Sustainable

Economic Growth: Empirical

Analysis with Spatial Spillover Effects from Yellow River Basin, China.

Sustainability 2022, 14, 2742.

https://doi.org/10.3390/su14052742

Academic Editor: Antonio Boggia

Received: 10 January 2022

Accepted: 22 February 2022

Published: 25 February 2022

Publisher's Note: MDPI stays neutral with regard to jurisdictional claims in published maps and institutional affiliations.

Copyright: (c) 2022 by the authors. Licensee MDPI, Basel, Switzerland. This article is an open access article distributed under the terms and conditions of the Creative Commons Attribution (CC BY) license (https:// creativecommons.org/licenses/by/ $4.0 /)$.

\begin{abstract}
Water and land resources are related to the security and stability of agricultural production, and the degree of matching in time and space directly affects regional agricultural production capacity and sustainable agricultural development. This paper intends to use the panel data of nine provinces in the Yellow River Basin from 2000 to 2019 and incorporate the static and dynamic spatial Durbin models with spatial effects under the geographical adjacency matrix and the comprehensive weight matrix of economic geography, so as to explore the direct effects and indirect effects, short-term effects and long-term effects of the matching coefficient of agricultural water and land resources on the agricultural economic growth in the Yellow River Basin. The results show the following: (1) The matching situation of agricultural water and land resources in different provinces along the Yellow River Basin are different; some are relatively short of water resources, some are relatively balanced in water and land resources, and some are relatively short of land resources. (2) The static spatial Durbin model shows that the direct effect of the matching coefficient of agricultural water and land resources on the agricultural economic growth of the province is not significant; the indirect effect and the total effect of the spatial spillover is significantly positive. (3) The dynamic spatial Durbin model under the two matrix forms shows that the short-term total effect of the matching coefficient of agricultural water and land resources on agricultural economic growth is significantly positive, while the long-term total effect is significantly negative, and the direction and degree of the short-term and long-term effects are inconsistent. This study provides a comprehensive analysis framework from the perspective of local and neighborhood effect, and short-term and long-term effect, which can provide a reference to reasonably adjust the matching of agricultural water and land resources to promote agricultural sustainable economic growth, especially for developing countries.
\end{abstract}

Keywords: water and land resources matching; spatial spillover effect; static spatial Durbin model; dynamic spatial Durbin model

\section{Introduction}

Recently, the report "The State of the World's Land and Water Resources in Food and Agriculture: The System Is At Its Limits", released by the Food and Agriculture Organization of the United Nations, has analyzed the development trends of land, soil, and water utilization, and emphasized that the conditions of the earth's soil, land, and water resources continue to deteriorate. It is estimated that by 2050 , it will be difficult to meet the 
food needs of nearly 10 billion people worldwide. Among them, the global anthropogenic soil degradation affects 1.66 billion hectares of agricultural land, accounting for $34 \%$ of the total area. From 2000 to 2017, the per capita land area has been reduced by nearly one-fifth and there is very little high-yield land for further development. Water shortages have severely endangered global food security and sustainable agricultural development, and at the same time endangered the livelihoods of 3.2 billion in agricultural areas. In this context, the protection and innovative use of land, soil, and water resources by mankind and the reversal of the deteriorating trend of land and water resources have become an important agenda for the development of global agricultural security now and in the future. In China, the Yellow River is the birthplace of culture. It still provides irrigation and soil for several provinces and hundreds of millions of people. How to make good use of the water and land resources in the basin to achieve better agricultural production and agricultural development is a problem that the Chinese government is trying to solve.

The ecological environment of the Yellow River Basin is fragile. The regional and structural lack of water and land resources in the watershed, land-erosion, land-desertification, and other phenomena frequently occur, and the endowment of water and land resources varies greatly among different provinces in the basin, making the coordination of water and land resources between provinces face huge challenges. Water and land resources are essential elements and basic supports for agricultural production activities. Agricultural production is inseparable from the reasonable matching of water and land resources. High matching of water and land resources is conducive to promoting agricultural economic growth. On the contrary, low matching of water and land resources may lead to unsustainable agricultural production and affect the safety of agricultural development.

In recent years, with the gradual advancement of agricultural modernization, the contradiction between the limited total amount of water and land resources, the problem of nonpoint source pollution of water and land resources [1], and the strong demand for water and land resources from agricultural economic growth have become more and more significant. The total water consumption of the nine provinces in the Yellow River Basin increased from 120.27 billion cubic meters in 2000 to 128.11 billion cubic meters in 2019, an increase of $6.52 \%$, of which agricultural water consumption fell from 88.46 billion cubic meters in 2000 to 81.71 billion cubic meters in 2019, a decrease of $7.63 \%$. The agricultural water consumption accounted for the total water consumption dropped from $73.55 \%$ in 2000 to $63.78 \%$ and cultivated land resources increased from 39,325.61 hectares in 2000 to $46,078.25$ hectares in 2019. On the one hand, the proportion of agricultural water consumption decreased, indicating that water for agricultural development is squeezed by industrial water, domestic water, and ecological water. Agricultural development may be restricted by agricultural water. On the other hand, the area of arable land increased. It shows that the agricultural water consumption per unit of arable land has decreased and intensified the conflict between water and soil in agricultural production, which is not conducive to agricultural production. In addition, affected by soil characteristics and soil quality, land desertification in the upper reaches of the Yellow River, desertification and erosion of land in the middle reaches, and salinization of land in the lower reaches are prominent. Soil carbon content is low, water penetration and retention are difficult, and soil degradation is serious [2]. Therefore, it is necessary to discuss the actual situation of agricultural water and land matching, as well as the direction and extent of the impact of agricultural water and land resources on the agricultural economic growth of the Yellow River Basin in recent years.

At the same time, the water and land resources in the provinces of the Yellow River Basin are unevenly distributed in time and space, and the regions and structures of the water and land resources are unreasonable [1]. There are significant differences in agricultural economic development among the provinces, and the conditions of the matching of water and land resources are different. Then, in this context, it is of great significance to explore the spatiotemporal matching relationship of agricultural water and land resources, and to deeply analyze the impact of agricultural water and land resources matching on the 
sustainable development of agriculture in the Yellow River Basin. Studying the spatial differentiation law of the matching of agricultural water and soil resources can provide a basis for the efficient use of water and soil resources in various provinces, management decision-making, and agricultural production.

\section{Literature Review}

Water and land problems in the Yellow River Basin have a long history. Although soil and water conservation policy has made significant contributions to the development of the Yellow River Basin and the reduction of sedimentation over the past 60 years, some challenges remain. Soil erosion, sediment load, and flooding are issues of great concern to the Yellow River Basin [3-5]. The Yellow River Basin is greatly affected by the monsoon, and the regional and seasonal precipitation distribution is extremely uneven [6]. The loess in the middle reaches of the Yellow River is extremely susceptible to erosion, resulting in a very large sediment load and concentration in the Yellow River [7]. The abundance of water resources affects the utilization and production efficiency of land resources, and the degree of reclamation of land resources also restricts the development of water resources. In addition to the input of water resources and land resources, the spatial matching degree of the two directly affects the sustainable development of agriculture [8]. Historically, large-scale soil erosion in the Yellow River Basin in China has led to soil degradation, water shortages, and loss of arable land, resulting in a decline in crop yields and a great impact on agricultural production [9]. Agricultural production along the Yellow River and nine provinces is constrained by water and land resources to a certain extent, among which the water resource constraint has slowed down but still exists, and the land resources constraint has increased rapidly; these are the main constraints on agricultural production at present [10]. The Yellow River Basin is a resource-based, water-scarce area, and the pressure on water and land resources is relatively high [1]. The upper reaches of the Yellow River are water conservation areas and an important water supply area for the Yellow River, while the middle and lower reaches are areas with rigid demands for water, where water sources and users are not located [11,12]. In addition, the proportion of agricultural water use has been declining, the proportion of industrial water and domestic water has been rising, and the contradiction between supply and demand of water resources is prominent [13]. In addition, the "2019 National Cultivated Land Quality Grade Bulletin" issued by the Ministry of Agriculture and Rural Affairs shows that the main grades of cultivated land quality in the Yellow River Basin are 4 to 6, some areas of cultivated land are degraded, and the comprehensive productivity of cultivated land needs to be improved urgently [14]. The management and control of water resources and land resources are borders of each other and the failure to integrate the mutual feedback of the two leads to the "uncoordinated functions" of water and land resources, resulting in the contradiction between the supply and demand of water resources and the uncoordinated relationship between water and sand [15]. Comparative analysis of the agricultural water and land resources matching calculation method can be seen in the Appendix A, Table A1.

At present, the research on the matching of agricultural water and land resources in academia mainly focuses on the analysis of the characteristics of the time and space matching of agricultural water and land resources. The measurement methods mainly include the following: First, the matching coefficient method of agricultural water and land resources, which was mainly proposed by Liu [16] earlier; he believed that the matching coefficient of water and land resources refers to the temporal and spatial matching ratio between agricultural water resources and cultivated land resources. The calculation rule for the amount of water resources in the cultivated land area is very mature and has been recognized by many scholars. The matching coefficient of water and land resources is used to analyze the matching dynamics of water and land resources in different regions [16-23]. It has strong data availability, mature methods, and strong operability. Based on the matching coefficient of water and land resources in this narrow sense, Gao expanded it and defined it as a generalized agricultural water and land resource matching coefficient, combining the 
irrigation "blue water" and precipitation "green water" with the area of cultivated land to match the water and land matching status [24]. It fails to identify the uneven distribution of land and water resources within a region. Most studies use the total amount of water resources, available water resources, or irrigation water consumption (i.e., irrigation "blue water") to characterize the amount of water resources, and regional precipitation "green water" to characterize the contribution of agricultural production. The second is the Gini coefficient method. Based on the difference of water and land resources, the Lorentz curve is used to characterize the spatial matching relationship between agricultural irrigation water consumption and cultivated land area in each region [16,18,25-27]. It is impossible to quantitatively analyze the matching status of the overall water and land resources in a certain area. Of course, it is more to analyze the Gini coefficient and the matching coefficient of agricultural water and land resources. The third is other measurement methods. Xu used the Malmquist DEA model to analyze the water and land resources utilization efficiency and matching characteristics of Gansu inland river basins using water resources and arable land resources as input indicators, and agricultural production value as output indicators [28]. It uses water resources and cultivated land resources, as model inputs cannot fully reflect the influencing factors of agricultural output value. Gao used the coefficient of variation and Spearman's rank correlation coefficient to analyze the proportions of "green water" and "blue water" in the Yellow River Basin and the trend of the coefficient of variation and correlation coefficients to explore the matching of water and land resources in each province [24].

The above studies are mostly about the current situation or characteristics of the matching of agricultural water and land resources, and seldom involve the study of the relationship with agricultural economic growth. In general, a separate study of water resources or land resources has more influence on agricultural economic growth $[29,30]$. Peng used the tail-effect model of water and land resources and, through ordinary panel regression analysis, they believed that the water and land resources in the Hengduan Mountain area had a restrictive effect on economic development [31]. Xu and Fan used the spatial Durbin model to study the spatial spillover effects of water and land resources matching and agricultural economic growth $[19,32]$. The former believes that the agricultural economic growth of various provinces in my country is spatially correlated, and the degree of water and land matching has an impact on the space of agricultural economic growth in each province. The spillover effect is significantly positive [18]. The latter analyzes the impact of water and land matching in the Yangtze River Economic Zone on agricultural economic growth and concludes that the spatial effect of the agricultural matching degree in the Yangtze River Economic Zone on agricultural economic growth is not significant [29]. Compiling the existing literature, we found that the research on the matching of agricultural water and land resources mainly focuses on the matching state and characteristics of water and land resources, considering the temporal and spatial distribution pattern of water and land resources. The existing results provide certain theoretical guidance for studying the impact of matching of water and land resources on agricultural economic growth in the Yellow River Basin but there is still room for research.

Existing research mainly investigate from the perspectives of resources and environmental sciences and geography, and seldom extend from economics. $\mathrm{Xu}$ and Fan are among the few who have carried out analysis of spatial spillover effects between water and land resources matching and agricultural economic growth from the perspective of spatial economics [19,32]. Their limitation lies in the analysis of the spatial Durbin model only from the geographic proximity matrix. The spatial relationship between regions is not only the geographic proximity relationship but also geographic distance, economic distance, economic geographic relationship, etc. The spatial effects they bring may be significantly different, so multiple matrices can be selected for model estimation to enhance the accuracy of the model's interpretation of reality. Second, they only consider the static impact of water and land resources matching on agricultural economic growth, and the dynamic impact of 
water and land resource matching on agricultural economic growth is not considered in the short and long term.

Based on this, this paper uses the data of nine provinces in the Yellow River Basin from 2000 to 2019 and uses spatial statistics and spatial measurement methods to explore the impact of water and land resources matching on the agricultural economic growth of the Yellow River Basin. On the one hand, the matching coefficient of agricultural water and land resources is measured and calculated, and the Moran's I index of global spatial autocorrelation and local spatial autocorrelation is used to analyze whether the matching coefficient of agricultural water and land resources is spatially related to agricultural economic growth. On the other hand, the geographical proximity matrix and Comprehensive weight matrix of economic geography, using static and dynamic spatial Durbin model (SDM) to explore the direction and extent of the impact of water and land resources matching coefficient on agricultural economic growth from direct effects, indirect effects, short-term effects, and long-term effects, so as to find the law of spatial differentiation and the reasons for the differentiation, it can provide policy reference for enhancing the matching ability of water and land resources and promoting the growth of agricultural economy in the Yellow River Basin.

\section{Data, Methods, and Models}

\subsection{Estimation of Agricultural Water and Land Resources}

3.1.1. Calculation of the Matching Coefficient of Agricultural Water and Land Resources in the Yellow River Basin

The matching coefficient of agricultural water and land resources is used to measure the temporal and spatial matching degree of water resources and land resources in agricultural development. The more water resources per unit land area, the higher the matching degree and the better the agricultural production conditions. Drawing lessons from Liu [16], this paper selects nine provinces in the Yellow River Basin as the basic research unit for the matching coefficient of agricultural water and land resources. Measured by the unit arable land area-total water resources method, the specific coefficient calculation model is

$$
M C_{i j}=\frac{W_{i j} a_{i j}}{L_{i j}}
$$

Among them, $M C_{i j}$ is the matching coefficient of agricultural water and land resources in a province of the Yellow River Basin, Ten thousand $\mathrm{m}^{3} / \mathrm{hm}^{3} ; w_{i j}$ is the total water resources, billion $\mathrm{m}^{3} ; a_{i j}$ is the proportion of agricultural water use; $L_{i j}$ is the cultivated land area, ten thousand $\mathrm{hm}^{3}$; $i$ represents the province, $i=1,2 \cdots 9$; and $j$ represents the year, $j=2000,2001 \cdots 2019$. We calculated the average water and land resource matching coefficient from 2000 to 2019. When $M C<0.9$, it means that the water resources per unit of arable land are relatively short. When $0.9 \leq M C \leq 1.1$, it means that the water and land resources are relatively balanced and the matching is relatively good; when $M C>1.1$, it means that the water resources per unit of arable land are relatively rich.

3.1.2. Calculation of Equivalent Coefficient of Agricultural Water and Land Resources in the Yellow River Basin

The equivalent coefficient of agricultural water and land resources is used to measure the rate of consumption or the degree of abundance-that is, the ratio of the matching coefficient of agricultural water and land resources to the natural matching coefficient of regional water and land resources is used to analyze the shortage of agricultural water and land resources in the Yellow River Basin. Drawing lessons from Li [33], we summarize the equivalent coefficient calculation model as follows:

$$
E C_{i j}=\frac{M C_{i j}}{N M C_{i j}}=\frac{A W_{i j}}{L_{i j}} / \frac{W_{i j}}{A L_{i j}}
$$


Among them, $E C_{i j}$ is the agricultural water and land-resource equivalent coefficient of a certain province in the Yellow River Basin; $M C_{i j}$ is the agricultural water and land resources matching coefficient of a certain province in the Yellow River Basin-that is, the agricultural water consumption per unit of arable land in a certain province; $N M C_{i j}$ is the natural matching coefficient of agricultural water and land resources of a certain province in the Yellow River Basin-that is, the amount of water resources per unit of land area in a province; $A W_{i j}$ is the total agricultural water consumption of each province, billion $\mathrm{m}^{3}$; $L_{i j}$ is the arable land area, ten thousand $\mathrm{hm}^{3} ; W_{i j}$ is the total water resource, billion $\mathrm{m}^{3}$; $A L_{i j}$ is the total land area of each province, ten thousand $\mathrm{hm}^{3} ; i$ represents the province, $i=1,2 \cdots 9$; and $j$ represents the year, $j=2000,2001 \cdots 2019$.

When $E C<1$, it indicates that water resources are sufficient and land resources are lacking; when $E C=1$, it indicates that the water and land resources are matched; when $E C>1$, it indicates that water resources are lacking, agricultural water use is restricted, and land resources are relatively sufficient. At this time, this article will further evaluate the shortage of agricultural water and land resources in the Yellow River Basin, adjust according to the division of Geng [34], and calculate the equivalent coefficient of agricultural water and land resources from 2000 to 2019 . When $E C<0.9$, it means that land resources are relatively short; when $0.9 \leq E C \leq 1.1$, it means that water and land resources are relatively balanced; when $E C>1.1$, it means that water resources are at a relative shortage.

It can be seen in Figure 1 that panel a represents the distribution of the agricultural water and land-resource matching coefficient in the Yellow River province and panel $b$ represents the distribution of the agricultural water and land resources equivalent coefficient in the Yellow River province. From the matching pattern of agricultural water and land resources in the Yellow River Basin, it can be seen that Shanxi, Inner Mongolia, Shandong, Gansu, and Ningxia are areas with relatively short water resources [35], and water resources per unit of arable land are relatively scarce. Shaanxi is an area with relatively balanced water and land resources, and water resources can basically meet the needs of arable land. Henan, Sichuan, and Qinghai are areas with relatively scarce land resources. At the same time, it can be seen from the matching coefficient of agricultural water and land resources that Sichuan and Qinghai are particularly rich in resources. The conclusion is consistent with that of Gao (see Table 1 for details) [24].

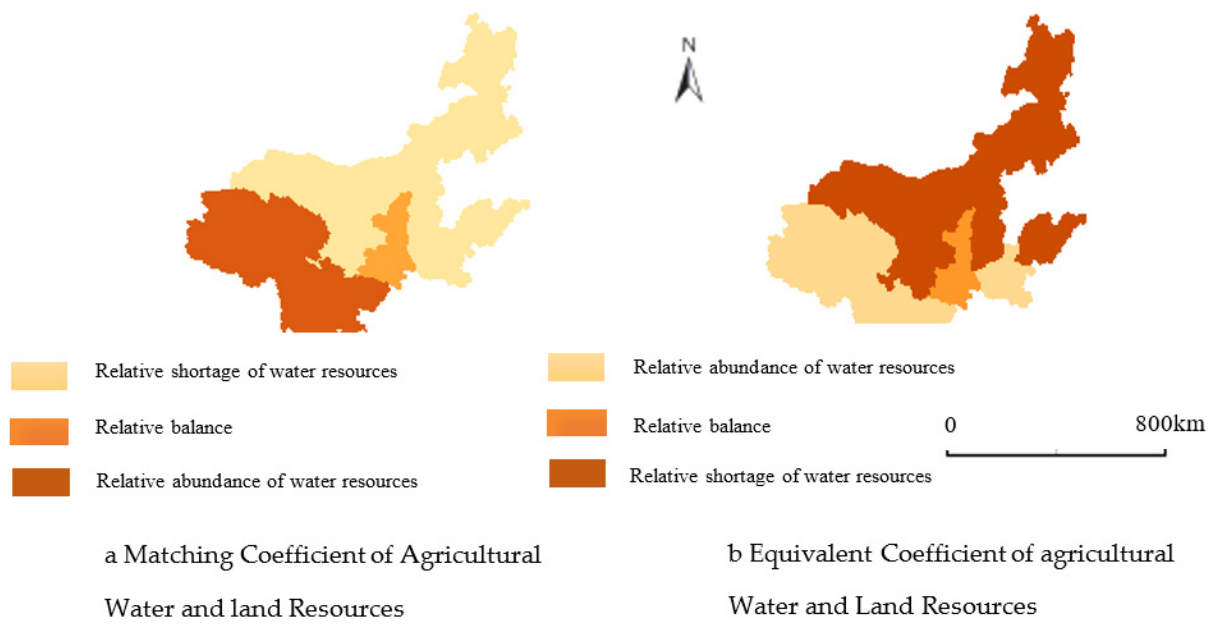

Figure 1. Matching pattern of agricultural water and land resources in the Yellow River Basin. 
Table 1. 2000-2019 average water and land resources matching coefficient and agricultural water and land resources equivalent coefficient.

\begin{tabular}{cccc}
\hline Province & $\begin{array}{c}\text { Agricultural Water and Land } \\
\text { Resources Matching Coefficient }\end{array}$ & $\begin{array}{c}\text { Agricultural Water and Land } \\
\text { Resources Equivalent Coefficient }\end{array}$ & $\begin{array}{c}\text { Degree of Shortage of Agricultural } \\
\text { Water and Land Resources }\end{array}$ \\
\hline Shanxi & 0.1431 & 1.4142 & Relative shortage of water resources \\
Inner Mongolia & 0.4464 & 2.7401 & Relative shortage of water resources \\
Shandong & 0.2805 & 0.8724 & Relative shortage of water resources \\
Henan & 0.3008 & 0.2363 & Relative abundance of water resources \\
Sichuan & 3.3066 & 1.0506 & Relative abundance of water resources \\
Shaanxi & 0.9254 & 3.4063 & Relative balance \\
Gansu & 0.4647 & 0.0412 & Relative shortage of water resources \\
Qinghai & 9.3734 & 32.7365 & Relative abundance of water resources \\
Ningxia & 0.0767 & Relative shortage of water resources & \\
\hline
\end{tabular}

\subsection{Spatial Correlation Test}

In this paper, from the global spatial autocorrelation and local spatial autocorrelation, the dependent variable agricultural economic growth and the core independent variable agricultural water and land resources matching coefficient are tested for spatial autocorrelation to determine whether there is spatial autocorrelation and whether the spatial econometric model can be used for analysis. The global and local spatial autocorrelation is generally measured by Moran's I index. The formula of the global Moran's I index is

$$
I=\frac{\sum_{i=1}^{n} \sum_{j=1} W_{i j}\left(Y_{i}-\bar{Y}\right)\left(Y_{j}-\bar{Y}\right)}{S^{2} \sum_{i=1}^{n} \sum_{j=1}^{n} W_{i j}}
$$

In the formula, $S^{2}=\frac{1}{n} \sum_{i=1}^{n}\left(Y_{i}-\bar{Y}\right) \bar{Y}=\frac{1}{n} \sum_{i=1}^{n} Y_{i}, Y_{i}$ represents the observed value of region $i ; n$ is the number of regions (nine provinces in this test); and $W_{i j}$ is the weight matrix. This article will use the geographic adjacency matrix for analysis. The adjacency criterion for the geographic adjacency matrix is as follows: when province $i$ and province $j$ are adjacent, the value is 1 ; when they are not adjacent, it is 0 . The global Moran's I index can be considered as the sum of the products of the observations in various regions and its value range is $[-1,1]$. If the Moran's $I$ index is greater than 0 , it indicates a global positive correlation-that is, similar attribute values have a geographical spatial aggregation distribution; if it is less than 0 , it means negative correlation - that is, there is an aggregate distribution of different attribute values; if it is equal to 0 , it means that the space is not correlated, and the adjacent areas are independent and randomly distributed $[36,37]$.

In order to explore the spatial correlation of spatially heterogeneous regions, the local Moran's I index is introduced, and its formula is expressed as

$$
I_{i}=Z_{i} \sum_{j=1}^{n} Z_{j}
$$

In the formula, $Z_{i}$ and $Z_{j}$ are the standard values of the observed values of areas $i$ and $j$, respectively. If Moran's $I$ index is greater than 0 , it indicates local autocorrelationthat is, high-high or low-low aggregation; if it is less than 0 , it indicates local negative correlation - that is, there is high-low or low-high aggregation; if it is equal to 0 , it means no correlation.

\subsection{Spatial Measurement Model Construction}

The focus of this paper is the impact of the spatial spillover effect of the matching of agricultural water and land resources on the agricultural economic growth of the Yellow River Basin [38]. As there may be spatial spillover or spatial path dependence between regions, this paper intends to construct a static spatial Durbin model. It not only considers 
the impact of local independent variables on the agricultural economic growth of the region, but also considers the impact of other variables (independent variables of other regions) on the agricultural economic growth of the region. The model is expressed as follows:

$$
\begin{aligned}
& t v_{i t}=\alpha_{0}+\rho W t v_{i t}+\alpha m c_{i t}+\beta c a_{i t}+\varphi h c_{i t}+\delta r w_{i t}+\phi a m_{i t}+\omega a e_{i t}+\alpha^{\prime} W m c_{i t}+\beta^{\prime} W c a_{i t}+\varphi^{\prime} W h c_{i t} \\
& +\delta^{\prime} r w_{i t}+\phi^{\prime} a m_{i t}+\omega^{\prime} a e_{i t}+\varepsilon_{i t}
\end{aligned}
$$

Among them, $t v_{i t}$ is the total output value of agriculture, forestry, animal husbandry, and fishery; $\alpha_{0}$ is a constant term; and $W$ is a spatial weight matrix. This article intends to construct a spatial Durbin model in two forms of geographic adjacency matrix and economic geography comprehensive weight matrix. The geographic adjacency matrix has been mentioned above; thus, it will not be repeated here. Since the geographic adjacency matrix cannot fully reflect the objective facts of regional association [39], the comprehensive weight matrix of economic geography is added to construct a comprehensive weight matrix $W=G \times E$, where $G$ is the geographic distance weight matrix, the main diagonal element of the matrix is 0 , the expression of nonprimary diagonal elements is $G_{i j}=\frac{1}{d_{i j}^{2}}(i \neq j)$; $d_{i j}$ is the Euclidean distance; $E$ is the economic distance weight matrix, drawing on the calculation rule of Sun [40] using the reciprocal of the regional per capita GDP difference as the measurement index of economic distance. The formula for nonmain diagonal elements is as follows: $E_{i j}=\frac{1}{\left|\overline{y_{i}}-\overline{y_{j}}\right|}(i \neq j)$. Among them, $\overline{y_{i}}$ and $\overline{y_{j}}$ are the average per capita GDP of the region $i$ and region $j$ from 2000 to 2019. $\rho W t v_{i t}$ is the spatial lag term of the total output value of agriculture, forestry, animal husbandry, and fishery, which is the explained variable. $\rho$ is the spatial lag coefficient. $m c_{i t}, c a_{i t}, h c_{i t}, r w_{i t}, a m_{i t}, a e_{i t}$, respectively, indicate the matching index of agricultural water and land resources, rural capital stock, rural human capital, rural employees, total power of agricultural machinery, and agricultural fiscal expenditure. $\alpha, \beta, \varphi, \delta, \phi, \omega$ are the coefficient of each explanatory variable. $W m c_{i t}$, $W c a_{i t}, W h c_{i t}, W r w_{i t}, W a m_{i t}, W a e_{i t}$ are the spatial lags of explanatory variables and the coefficient is $\alpha \prime, \beta \prime, \varphi^{\prime}, \delta \prime, \phi^{\prime}, \omega \prime ; \varepsilon_{i t}$ is the random error term; $i$ represents province $i$; $i=1,2 \cdots 9$; and $t$ represents year $t, j=2000,2001 \cdots 2019$.

This research also involves the spatial correlation between the dependent variable and the independent variable. Due to the long-term accumulation of agricultural water and land resources, agricultural capital stock, and rural human capital, the growth of the agricultural economy in the Yellow River Basin is often affected by the previous agricultural development factors and the level of agricultural development. Further, because the factors of production flow in various provinces and are not independent of each other [41], the agricultural economic development of a region will also be affected by the factors of agricultural production or the level of agricultural development in neighboring regions or related regions, forming time dependence and spatial spillover. Therefore, it is possible to establish a generalized dynamic spatial Durbin model that includes time effects, space effects, and space-time effects, and includes the dependent variable lags by one period. The model is expressed as follows:

$$
\begin{aligned}
& t v_{i t}=\tau t v_{i, t-1}+\rho W t v_{i t}+\alpha m c_{i t}+\beta c a_{i t}+\varphi h c_{i t}+\delta r w_{i t}+\phi a m_{i t}+\omega a e_{i t}+ \\
& \alpha^{\prime} W m c_{i t}+\beta^{\prime} W c a_{i t}+\varphi^{\prime} W h c_{i t}+\delta^{\prime} r w_{i t}+\phi^{\prime} a m_{i t}+\omega^{\prime} a e_{i t}+\mu_{i}+\gamma_{t}+\varepsilon_{i t}
\end{aligned}
$$

Among them, $t v_{i, t-1}$ is the first-order lag of the explained variable $t v_{i t}, \mu_{i t}$ is the individual effect, $\gamma_{i t}$ is the time effect, and the others are the same.

\subsection{Variable Selection and Data Sources}

\subsubsection{Variable Selection}

This article intends to study the impact of the matching of agricultural water and land resources and spatial overflow on the agricultural economic growth of the Yellow River Basin. Based on the comprehensive weight matrix of geographic adjacency and economic geography, the data of nine provinces in the Yellow River Basin from 2000 to 2019 are 
selected for spatial Durbin model analysis. The specific index selection and data processing are as follows (see Table A2 in the Appendix A, for details):

Interpreted variable - total output value of agriculture, forestry, animal husbandry, and fishery $(t v)$. This paper selects the total output value of agriculture, forestry, animal husbandry, and fishery to measure the agricultural economic growth of the provinces in the Yellow River Basin. In order to eliminate the impact of price changes, the regional GDP is set at a constant price in 2000; then, we calculate the actual total output value of agriculture, forestry, animal husbandry, and fishery in each province based on the total output value index of agriculture, forestry, animal husbandry, and fishery.

Explanatory variable: core variable, agricultural water and land resources matching index $(m c)$. See above for details. Control variables include rural capital stock $(c a)$. This article selects the capital stock of each city from 2000 to 2019, and draws on Zhang, J. [38]'s interprovincial capital stock method for calculation. The adjusted calculation formula is as follows: $c a_{i t}=c a_{i t-1}\left(1-\delta_{i t}\right)+I_{i t}$, where $c a_{i t}$ is the rural capital stock and $c a_{i t-1}$ is the rural capital stock of the previous year; $I_{i t}$ is the total fixed capital investment in rural areas; $i$ represents the province $i$; $t$ represents the year $t ; \delta_{i t}$ is the depreciation rate, which is $9.6 \%$. Rural human capital $(h c)$. In this paper, rural human capital is measured by the average years of education-specifically, 6 years for elementary school, 9 years for junior high school, 12 years for high school, and 16 years for junior college and above. It also includes rural employees $(r w)$, total power of agricultural machinery $(a m)$, and agricultural fiscal expenditure (ae).

\subsubsection{Data Source and Variable Description}

(1) Data source. The data in this article come from the "China Statistical Yearbook", "China Rural Statistical Yearbook", "China Population and Employment Statistical Yearbook", "Yellow River Statistical Yearbook", provincial statistical yearbooks, China Water Resources Bulletin, Yellow River Water Resources Bulletin, Provincial Water Resources Bulletin, Qianzhan [Qianzhan, https:/ /www.qianzhan.com/, accessed on 2 April 2021].

(2) Variable description. The descriptive statistical analysis results of each variable are shown in the following Table 2.

Table 2. Descriptive statistics of main variables.

\begin{tabular}{|c|c|c|c|c|c|c|}
\hline Variables & Unit & $\begin{array}{l}\text { Sample } \\
\text { Size }\end{array}$ & Mean & $\begin{array}{l}\text { Standard } \\
\text { Deviation }\end{array}$ & Minimum & Maximum \\
\hline $\begin{array}{l}\text { Total output value of agriculture, forestry, } \\
\text { animal husbandry, and fishery }(t v)\end{array}$ & Tens of billions yuan & 180 & 23.9030 & 25.4690 & 0.5700 & 96.7170 \\
\hline $\begin{array}{c}\text { Agricultural water and land resources } \\
\text { matching coefficient }(m c)\end{array}$ & Ten thousand $\mathrm{m}^{3} / \mathrm{hm}^{3}$ & 180 & 1.7000 & 2.9750 & 0.0460 & 12.4860 \\
\hline Capital stock $(c a)$ & Tens of billions yuan & 180 & 18.1140 & 26.4800 & 0.0170 & 136.4650 \\
\hline Rural human capital $(h c)$ & Hour & 180 & 8.1420 & 0.4320 & 7.3190 & 9.8860 \\
\hline Rural workers $(r w)$ & Million people & 180 & 17.8040 & 15.5630 & 1.7200 & 49.1500 \\
\hline Total power of agricultural machinery (am) & Million kilowatts & 180 & 35.9140 & 35.5500 & 2.5620 & 135.0000 \\
\hline Agricultural fiscal expenditure (ae) & Tens of billions yuan & 180 & 2.9840 & 3.0780 & 0.0480 & 12.4110 \\
\hline
\end{tabular}

\section{Empirical Results and Analysis}

\subsection{Spatial Correlation Analysis}

\subsubsection{Global Spatial Autocorrelation Analysis}

Table 3 shows the results of the global spatial correlation between agricultural economic growth and the matching coefficient of agricultural water and land resources in the Yellow River Basin from 2000 to 2019. The results show that most of the Moran's I of the total output value of agriculture, forestry, animal husbandry, and fishery in each year passed the $5 \%$ significance test, and the Moran value was positive. The correlation degree of the agricultural economic growth of each province reached its peak in 2010, showing an overall downward trend; Moran's I of the matching coefficient of agricultural water and 
land resources mostly passed the $5 \%$ significance test, some passed the $1 \%$ significance test, and the Moran value was positive and it was found that Moran's I showed a downward trend in fluctuations. It shows that there is a spatial correlation between the agricultural economic growth of the Yellow River Basin and the matching coefficient of agricultural water and land resources.

Table 3. The Moran index of the agricultural economic growth and the matching coefficient of agricultural water and land resources in the Yellow River Basin from 2000 to 2019.

\begin{tabular}{ccccc}
\hline Variables & \multicolumn{2}{c}{$\begin{array}{c}\text { Dependent Variable: } \\
\text { Agricultural Economic Growth }\end{array}$} & $\begin{array}{c}\text { Core Variable: Matching Coefficient of } \\
\text { Agricultural Water and Land Resources }\end{array}$ \\
\hline Times & Moran's I & Z Value & Moran's I & Z Value \\
\hline 2000 & $0.3510^{* *}$ & 2.1240 & $0.2630^{* *}$ & 2.2560 \\
2001 & $0.3590^{* *}$ & 2.1730 & $0.3470^{* * *}$ & 2.7670 \\
2002 & $0.3490^{* *}$ & 2.1110 & $0.3120^{* *}$ & 2.5400 \\
2003 & $0.3340^{* *}$ & 2.0950 & $0.2080^{* *}$ & 0.0270 \\
2004 & $0.3390^{* *}$ & 2.0730 & $0.2180^{* *}$ & 2.3040 \\
2005 & $0.3350^{* *}$ & 2.0450 & $0.1830^{* *}$ & 2.2580 \\
2006 & $0.3260^{* *}$ & 2.0210 & $0.1780^{* *}$ & 0.0240 \\
2007 & $0.2760^{* *}$ & 1.7740 & $0.1940^{* *}$ & 2.2820 \\
2008 & $0.3130^{* *}$ & 1.9540 & $0.2130^{* *}$ & 2.2890 \\
2009 & $0.3510^{* *}$ & 2.1480 & $0.1080^{* *}$ & 2.2170 \\
2010 & $0.3630^{* *}$ & 2.1900 & $0.1540^{* *}$ & 2.2000 \\
2011 & $0.3110^{* *}$ & 1.9430 & $0.2210^{* *}$ & 2.0230 \\
2012 & $0.2950^{* *}$ & 0.0630 & $0.1720^{* *}$ & 2.2870 \\
2013 & $0.3120^{* *}$ & 1.9580 & $0.1950^{* *}$ & 2.1370 \\
2014 & $0.3130^{* *}$ & 1.9640 & $0.0730^{* *}$ & 2.1060 \\
2015 & $0.2870^{*}$ & 1.8400 & $0.0880^{* *}$ & 2.2470 \\
2016 & $0.2550^{*}$ & 1.6700 & $0.1050^{* *}$ & 2.1670 \\
2017 & $0.2500^{*}$ & 1.6470 & $0.0800^{* *}$ & 2.3070 \\
2018 & 0.2430 & 1.6130 & $0.0900^{* *}$ & 2.2400 \\
2019 & 0.2300 & 1.5410 & $0.0890^{* *}$ & \\
\hline
\end{tabular}

Note: ${ }^{* *},{ }^{*}$ means passing the significance test at the levels of $5 \%$, and $10 \%$, respectively.

\subsubsection{Local Spatial Autocorrelation Analysis}

This article uses Moran scatter plots to observe the local spatial autocorrelation of agricultural economic growth and the matching coefficient of agricultural water and land resources in the Yellow River Basin from 2000 to 2019. Figures 2 and 3 show the spatial evolution process of agricultural economic growth and the matching coefficient of agricultural water and land resources in 2000, 2006, 2013, and 2019, respectively.
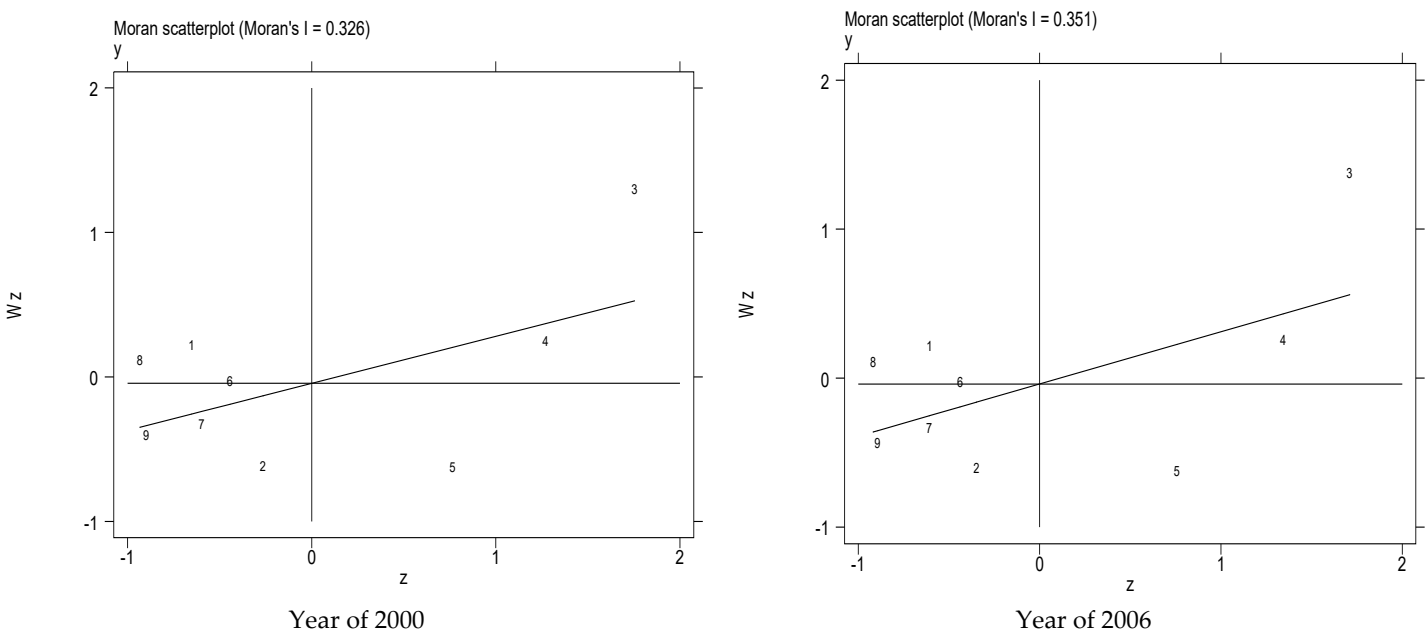

Figure 2. Cont. 

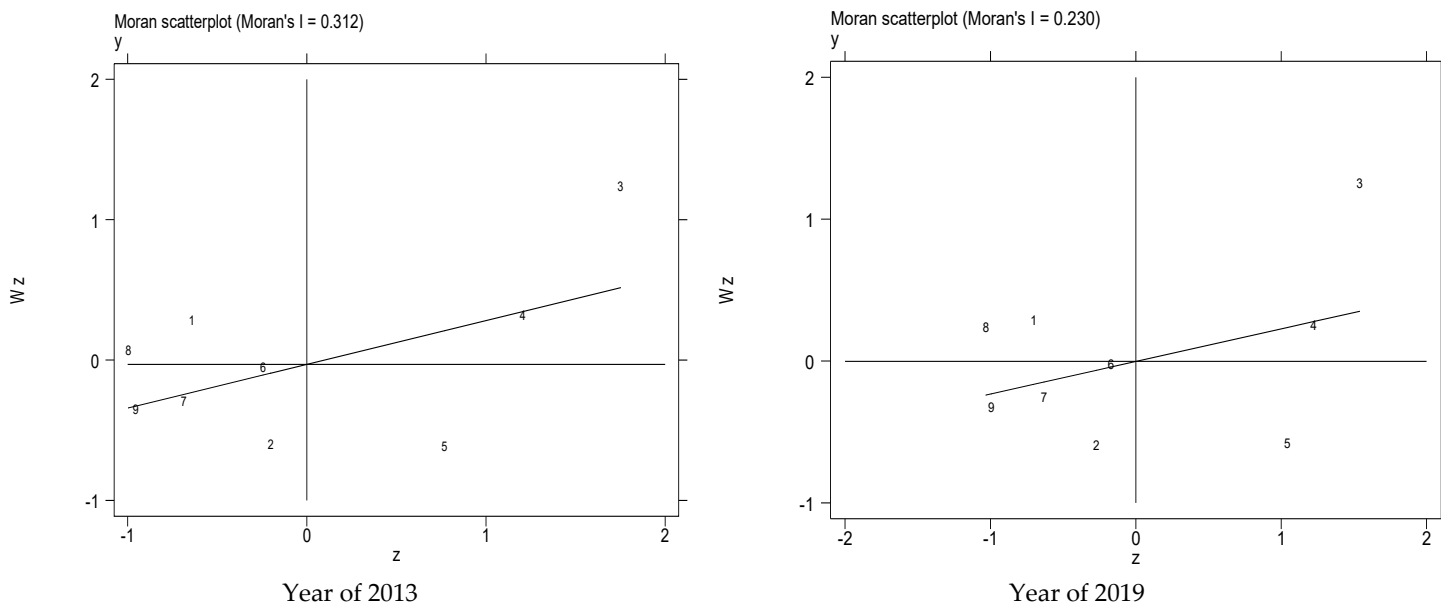

Figure 2. Scatter plot of agricultural economic growth Moran index.
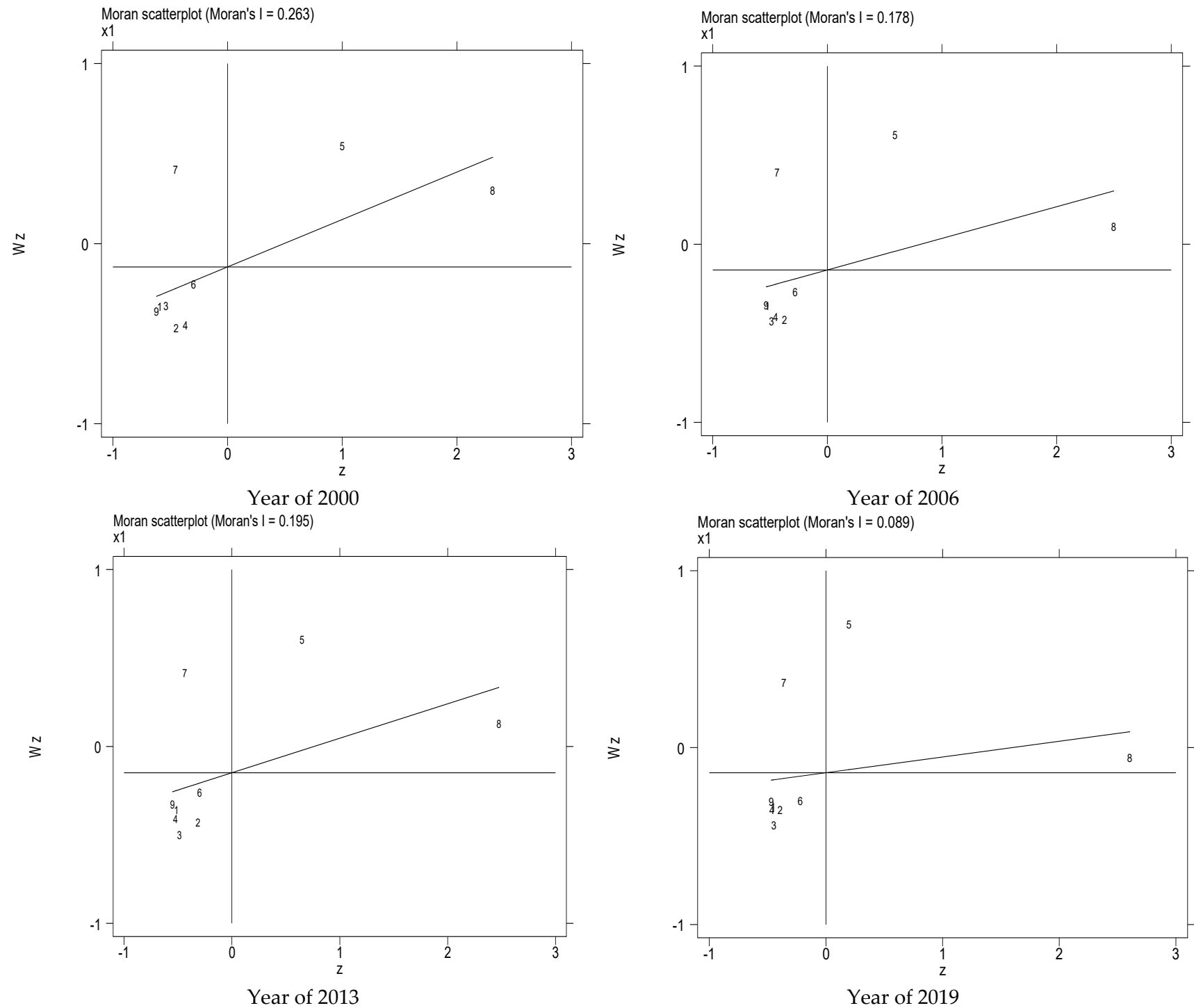

Figure 3. Scatter plot of Moran index of matching coefficient of agricultural water and land resources. 
It can be seen in Figure 2 that the spatial evolution of agricultural economic growth is generally stable. Shandong and Henan are located in the first quadrant and belong to the high-high agglomeration type, showing a spatial diffusion effect; Shanxi and Qinghai are located in the second quadrant and belong to the low-high agglomeration type, indicating that the agricultural economic growth of the provinces is low and the neighboring provinces are high, which belong to the transitional area of agricultural economic development; Inner Mongolia, Shaanxi, Gansu, and Ningxia are located in the third quadrant and belong to the low-low agglomeration type, indicating that the agricultural economic development level of this province and neighboring provinces is low. Sichuan is located in the fourth quadrant and belongs to the high-low aggregation type, indicating that the agricultural economic growth of this province is high and the neighboring provinces are low, showing a polarization effect. It can be seen that the agglomeration effect of areas with higher agricultural economic level is strong, and the spatial correlation degree is high, while the areas with lower agricultural economic level have weak agglomeration effect and low spatial correlation degree. The agglomeration of provincial agricultural economic growth shows high-high, low-low differentiation, indicating that the agricultural economic growth of the Yellow River Basin has geographic spatial dependence and heterogeneity [42].

It can be seen in Figure 3 that the agglomeration degree and structure of the matching coefficient of agricultural water and land resources have not changed and are highly stable. Sichuan and Qinghai are located in the first quadrant and belong to the high agglomeration type. The matching degree of agricultural water and land in these two provinces is obviously better than that of other provinces. The unit water resources are relatively abundant and other provinces are relatively short, which can exert a certain diffusion effect. Gansu is located in the second quadrant, belonging to the low-high agglomeration type, and belongs to the high-low transition zone of agricultural water and land resources matching; Shanxi, Inner Mongolia, Shandong, Henan, Shaanxi, and Ningxia are located in the third quadrant, belonging to the low-low agglomeration type, indicating that these provinces are clustered together because of the similar characteristics of poor agricultural water and land matching. They are very stable, and the phenomenon of water shortage has not been improved. The Moran index of the matching coefficient of agricultural water and land resources in the province mainly presents high-high, low-low differentiation, indicating that the matching coefficient of agricultural water and land resources in the Yellow River Basin also has spatial autocorrelation.

\subsection{Estimation Results and Analysis of Static Space Durbin Model}

\subsubsection{Selection of Model Estimation Form}

Regarding the selection and parameter estimation of the spatial panel model, this paper conducts LR test, Wald test, Hosman test, and joint significance test from the geographical adjacency matrix and economic geography comprehensive weight matrix in order to determine the appropriate spatial panel model [40]. The test results are shown in Table 4. It is found that in the form of geographic adjacency matrix, regarding the choice of spatial panel model, the LR test statistics of SDM (spatial Durbin model) and SAR (spatial autoregressive model) are 63.0000, and the LR test statistics of SDM and SEM (spatial error model) are 126.0000 , the $p$ value of both is 0.0000 , indicating that the null hypothesis is rejected at the $1 \%$ significance level. The Wald test is also performed on SAR and SEM, and the $p$ value is 0 . The null hypothesis is rejected at the $1 \%$ significance level. LR test and Wald test show that SDM cannot be degenerated into SAR and SEM; so, SDM is the best choice of spatial measurement model. Regarding the choice of random effects and fixed effects, the Hausman test statistic is 13.73 , which rejects the null hypothesis of random effects at the $5 \%$ significance level; so, the model should use the solid effects model.

Under the comprehensive weight matrix form of economic geography, the LR test statistic of SDM and SAR is 51.0000 and the LR test statistic of SDM and SEM (spatial error model) is 15.0000. The null hypothesis is significantly rejected at the $1 \%$ level. Perform Wald test on SAR and SEM, the $p$ value is 0 , and the null hypothesis is rejected at the $1 \%$ 
significance level; thus, SDM should also be selected. The Hausman test result shows that the null hypothesis of random effects is rejected at the $1 \%$ level, so the fixed effects model should be used.

Regarding individual fixed effects, time fixed effects, and time-space double fixed effects, this article uses a joint significance test to obtain the answer. The F statistic is 607.32, and the $p$ value is 0.0000 - that is, the null hypothesis of individual fixed effects is rejected at the $1 \%$ significance level. So, we choose the dual fixed effects model.

Table 4. Estimation test of various models.

\begin{tabular}{cccccc}
\hline Test Type & LR Test (sdm sar) & LR Test (sdm sem) & Wald Test (sar) & Wald Test (sem) & Hausman Test \\
\hline 0-1 matrix & 63.0000 & 126.0000 & 73.3300 & 58.0700 & 13.7300 \\
Comprehensive Weight & $(0.0000)$ & $(0.0000)$ & $(0.0000)$ & $(0.0000)$ & $(0.0328)$ \\
Matrix of & 51.0000 & 15.0000 & 25.7300 & 31.5400 & 121.2700 \\
Economic Geography & $(0.0000)$ & $(0.0000)$ & $(0.0002)$ & $(0.0000)$ & $(0.0000)$ \\
\hline
\end{tabular}

Note: The test statistics in the table, () is the $p$ value.

\subsubsection{Estimation Results and Analysis of Static Space Durbin Model}

By estimating the static spatial Durbin model under the geographical adjacency matrix and the comprehensive weight matrix of economic geography(see Table 5 for details), it is found that the spatial spillover coefficients of the explained variable-the total output value of agriculture, forestry, animal husbandry, and fishery to surrounding provinces are significantly negative at the level of $10 \%$, indicating that the province's agriculture economic growth will have a restraining effect on the agricultural economic growth of neighboring provinces. The core variable-the matching coefficient of agricultural water and land resources has no significant effect on the agricultural economic growth of the province. In addition, the matching coefficient of agricultural water and land resources under the geographical adjacency matrix is significantly positive at the $5 \%$ level, indicating that the matching status of local water and land resources will affect the surrounding agriculture economic growth has a positive impact and it is not significant in the form of a comprehensive weight matrix of economic geography.

Table 5. Static spatial Durbin model estimation results.

\begin{tabular}{|c|c|c|c|c|c|c|c|c|c|c|}
\hline \multirow{2}{*}{$\begin{array}{c}\text { Models } \\
\text { Variables }\end{array}$} & \multicolumn{5}{|c|}{ The Durbin Model of Geographic Adjacency Matrix Space } & \multicolumn{5}{|c|}{$\begin{array}{c}\text { The Spatial Durbin Model of Comprehensive Weight Matrix for } \\
\text { Economic Geography }\end{array}$} \\
\hline & Main & Wx & $\begin{array}{l}\text { Direct } \\
\text { Effect }\end{array}$ & $\begin{array}{l}\text { Indirect } \\
\text { Effect }\end{array}$ & $\begin{array}{l}\text { Total } \\
\text { Effect }\end{array}$ & Main & Wx & $\begin{array}{l}\text { Direct } \\
\text { Effect }\end{array}$ & $\begin{array}{l}\text { Indirect } \\
\text { Effect }\end{array}$ & $\begin{array}{l}\text { Total } \\
\text { Effect }\end{array}$ \\
\hline$m c$ & $\begin{array}{l}-0.1390 \\
(-0.270)\end{array}$ & $\begin{array}{l}1.3982 * * \\
(0.6801)\end{array}$ & $\begin{array}{l}-0.2096 \\
(0.2851)\end{array}$ & $\begin{array}{l}1.2651 * * \\
(0.6419)\end{array}$ & $\begin{array}{l}1.0554^{*} \\
(0.6265)\end{array}$ & $\begin{array}{c}0.0665 \\
(0.3086)\end{array}$ & $\begin{array}{l}-0.3431 \\
(0.5814)\end{array}$ & $\begin{array}{c}0.0974 \\
(0.3152)\end{array}$ & $\begin{array}{l}-0.3189 \\
(0.5247)\end{array}$ & $\begin{array}{l}-0.2216 \\
(0.6332)\end{array}$ \\
\hline$c a$ & $\begin{array}{l}0.0372 * \\
(0.0220)\end{array}$ & $\begin{array}{c}0.1386 * * * \\
(0.0413)\end{array}$ & $\begin{array}{l}0.0285 \\
(0.0226)\end{array}$ & $\begin{array}{c}0.1174 * * * \\
(0.0338)\end{array}$ & $\begin{array}{c}0.1459 * * * \\
(0.0286)\end{array}$ & $\begin{array}{c}0.0747^{* * *} \\
(0.0227)\end{array}$ & $\begin{array}{c}0.1500^{* * *} \\
(0.0686)\end{array}$ & $\begin{array}{c}0.0671^{* * *} \\
(0.0236)\end{array}$ & $\begin{array}{l}0.1156 \text { * } \\
(0.0616)\end{array}$ & $\begin{array}{r}0.1827 \\
(0.0594)\end{array}$ \\
\hline$h c$ & $\begin{array}{l}-0.0859 \\
(0.9937)\end{array}$ & $\begin{array}{c}-5.1262 \text { ** } \\
(2.4876)\end{array}$ & $\begin{array}{c}0.2904 \\
(0.9805)\end{array}$ & $\begin{array}{c}-4.4114^{* *} \\
(2.2091)\end{array}$ & $\begin{array}{c}-4.1211 \text { * } \\
(2.2420)\end{array}$ & $\begin{array}{c}0.3395^{* *} \\
(1.2281)\end{array}$ & $\begin{array}{c}1.7544 \\
(2.3393)\end{array}$ & $\begin{array}{c}0.3471^{* *} \\
(1.1469)\end{array}$ & $\begin{array}{c}1.6282 \\
(1.8968)\end{array}$ & $\begin{array}{c}1.9753^{* *} \\
(2.3604)\end{array}$ \\
\hline$r w$ & $\begin{array}{c}-1.322 * * * \\
(0.2155)\end{array}$ & $\begin{array}{l}-0.5026 \\
(0.4925)\end{array}$ & $\begin{array}{c}-1.319^{* * *} \\
(0.2155)\end{array}$ & $\begin{array}{l}-0.2013 \\
(0.4482)\end{array}$ & $\begin{array}{l}-1.5202 \\
(0.4498)\end{array}$ & $\begin{array}{c}-1.4895^{* *} \\
(0.2583)\end{array}$ & $\begin{array}{c}1.0344^{* * *} \\
(0.5172)\end{array}$ & $\begin{array}{c}-1.5720 \text { ** } \\
(0.2522)\end{array}$ & $\begin{array}{c}1.2072^{* * *} \\
(0.4365)\end{array}$ & $\begin{array}{c}-0.3649 \\
(0.4733)\end{array}$ \\
\hline$a m$ & $\begin{array}{c}0.5909^{* * *} \\
(0.0484)\end{array}$ & $\begin{array}{l}-0.0659 \\
(0.0958)\end{array}$ & $\begin{array}{c}0.6039^{* * *} \\
(0.0508)\end{array}$ & $\begin{array}{l}-0.1708 \\
(0.0807)\end{array}$ & $\begin{array}{c}0.4332^{* *} \\
(0.0639)\end{array}$ & $\begin{array}{c}0.4671^{* * *} \\
(0.0417)\end{array}$ & $\begin{array}{c}0.1589^{* * *} \\
(0.1176)\end{array}$ & $\begin{array}{c}0.4652^{* * *} \\
(0.0421)\end{array}$ & $\begin{array}{c}0.0408 \\
(0.0930)\end{array}$ & $\begin{array}{c}0.5060^{* * *} \\
(0.0937)\end{array}$ \\
\hline ae & $\begin{array}{c}4.2389 * * * \\
(0.3077)\end{array}$ & $\begin{array}{c}4.3929 * * * \\
(0.8568)\end{array}$ & $\begin{array}{c}4.0413^{* * *} \\
(0.2967)\end{array}$ & $\begin{array}{c}3.2496 \\
(0.6608)\end{array}$ & $\begin{array}{c}7.2908^{* * *} \\
(0.7825)\end{array}$ & $\begin{array}{c}3.6855^{* * *} \\
(0.3104)\end{array}$ & $\begin{array}{c}2.8926^{* * * *} \\
(0.9901)\end{array}$ & $\begin{array}{c}3.5897 * * * \\
(0.3027)\end{array}$ & $\begin{array}{l}1.8751 * * \\
(0.7525)\end{array}$ & $\begin{array}{c}5.4648^{* * *} \\
(0.8159)\end{array}$ \\
\hline $\mathrm{R}^{2}$ & 0.8625 & - & - & - & - & 0.8886 & - & - & - & - \\
\hline $\log -1$ & -395.2364 & - & - & - & - & -432.3894 & - & - & - & - \\
\hline rho & $\begin{array}{c}-0.1951 \text { * } \\
(0.1067)\end{array}$ & - & - & - & - & $\begin{array}{c}-0.2179 * \\
(0.1295)\end{array}$ & - & - & - & - \\
\hline sigma $^{2}$ & $\begin{array}{c}4.6764^{* * *} \\
(0.4961)\end{array}$ & - & - & - & - & $\begin{array}{c}6.1944^{* * *} \\
(0.6081)\end{array}$ & - & - & - & - \\
\hline
\end{tabular}

Note: ${ }^{* *}, * *,{ }^{*}$ means passing the significance test at the levels of $1 \%, 5 \%$, and $10 \%$, respectively. The values in () are statistical values, the same as below. 
Since the regression coefficient of the core variable-agricultural water and land resources matching coefficient is not significant and cannot directly reflect the degree of the explanatory variable's influence on the explained variable, the spatial effect of the agricultural water and land resources matching coefficient and other variables on the agricultural economic growth of the Yellow River Basin decomposed and characterized as Direct effect, indirect effect, and total effect are shown in Table 6.

Direct effect. The direct effects of the matching coefficient of agricultural water and land resources under the geographical adjacency matrix and the comprehensive weight matrix of economic geography are not significant, indicating that the current matching status of agricultural water and land resources has no significant impact on the agricultural economic growth of the Yellow River Basin. Regarding control variables, under the geographical adjacency matrix, the rural employed population, the total power of agricultural machinery, and the agricultural fiscal expenditure are significantly positive at the $1 \%$ level, indicating that the three variables have a positive effect on the growth of the agricultural economy. Under the economic geographic weight matrix, rural capital stock and rural human capital are significantly positive at the $1 \%$ and $5 \%$ levels, and rural employees are significantly negative at the $5 \%$ level, indicating that they are affected by differences in economic levels and geographic distances. Rural capital stock and human capital will have a positive effect on agricultural economic growth and rural employees will have a negative effect on agricultural economic growth.

Table 6. Dynamic spatial Durbin model estimation results.

\begin{tabular}{|c|c|c|c|c|c|c|c|}
\hline \multicolumn{4}{|c|}{$\begin{array}{c}\text { Dynamic Spatial Durbin Model of Geographic } \\
\text { Adjacency Matrix }\end{array}$} & \multicolumn{4}{|c|}{ Dynamic Spatial Durbin Model of Synthetic Weight Matrix } \\
\hline tv & $\begin{array}{l}1.4248^{* * *} \\
(0.03398)\end{array}$ & $W^{*} t v$ & $\begin{array}{c}0.2724^{* * *} \\
(0.0849)\end{array}$ & tv & $\begin{array}{c}1.3682 * * * \\
(0.0272)\end{array}$ & $W * t v$ & $\begin{array}{c}0.2439 * * \\
(0.1009)\end{array}$ \\
\hline$m c$ & $\begin{array}{c}0.7302 * * * \\
(0.1493)\end{array}$ & $W * m c$ & $\begin{array}{c}0.5043 \\
(0.3167)\end{array}$ & $m c$ & $\begin{array}{c}0.7124^{* * *} \\
(0.1326)\end{array}$ & $W^{*} m c$ & $\begin{array}{c}-0.02730 \\
(0.1839)\end{array}$ \\
\hline $\mathrm{ca}$ & $\begin{array}{l}-0.0227 * \\
(0.0127)\end{array}$ & $W * c a$ & $\begin{array}{l}0.1428^{* * *} \\
(0.0189)\end{array}$ & $\mathrm{ca}$ & $\begin{array}{c}0.0911^{* * *} \\
(0.0109)\end{array}$ & $W^{*} c a$ & $\begin{array}{l}-0.0059 \\
(0.0251)\end{array}$ \\
\hline$h c$ & $\begin{array}{l}9.0961^{* * *} \\
(0.5552)\end{array}$ & $W^{*} h c$ & $\begin{array}{l}40.8610 * * * \\
(1.1262)\end{array}$ & $h c$ & $\begin{array}{c}18.4305^{* * *} \\
(0.5086)\end{array}$ & $W * h c$ & $\begin{array}{c}38.7227 * * * \\
(0.8370)\end{array}$ \\
\hline$r w$ & $\begin{array}{c}-0.2712^{* *} \\
(0.1281)\end{array}$ & $W * r w$ & $\begin{array}{c}2.0216^{* * *} \\
(0.2363)\end{array}$ & $r w$ & $\begin{array}{c}0.6202^{* * *} \\
(0.1215)\end{array}$ & $W^{*} r w$ & $\begin{array}{c}2.2507 * * * \\
(0.2269)\end{array}$ \\
\hline$a m$ & $\begin{array}{l}-0.1787^{* * *} \\
(0.0329)\end{array}$ & $W^{*} a m$ & $\begin{array}{l}-0.1222^{* *} \\
(0.0501)\end{array}$ & $a m$ & $\begin{array}{c}-0.02156^{*} \\
(0.0225)\end{array}$ & $W^{*} a m$ & $\begin{array}{l}-4165^{* * *} \\
(0.0473)\end{array}$ \\
\hline ae & $\begin{array}{l}-2.8431^{* * * *} \\
(0.1797)\end{array}$ & $W^{*} a e$ & $\begin{array}{l}-4.4573^{* * *} \\
(0.3001)\end{array}$ & ae & $\begin{array}{c}-2.4693^{* * *} \\
(0.1649)\end{array}$ & $W^{*} a e$ & $\begin{array}{l}-5.7890^{* * *} \\
(0.3562)\end{array}$ \\
\hline $\mathrm{R}^{2}$ & 0.9187 & - & - & $\mathrm{R}^{2}$ & 0.8675 & - & - \\
\hline $\log -1$ & -830.3283 & - & - & $\log -1$ & -1096.4492 & - & - \\
\hline rho & $\begin{array}{c}0.1057 \\
(0.0705)\end{array}$ & - & - & rho & $\begin{array}{c}0.0997 \\
(0.08228)\end{array}$ & - & - \\
\hline sigma $^{2}$ & $\begin{array}{c}2.7287^{* * * *} \\
(0.1603)\end{array}$ & - & - & sigma $^{2}$ & $\begin{array}{c}3.2513 * * * \\
(0.1498)\end{array}$ & - & - \\
\hline
\end{tabular}

Note: ${ }^{* * * * * *},{ }^{*}$ means passing the significance test at the levels of $1 \%, 5 \%$, and $10 \%$, respectively.

Indirect effects. The spatial spillover effect of the matching coefficient of agricultural water and land resources under the geographical adjacency matrix is significantly positive at the $5 \%$ level, indicating that the matching degree of agricultural water and land resources in neighboring provinces will promote the province and its direct effect is not significant, indicating that the matching degree of agricultural water and land resources has a more significant impact on neighboring provinces than this province; so, it has a "demonstration effect" and "imitation effect" on neighboring provinces [18]. The matching coefficient of agricultural water and land resources under the comprehensive weight matrix of economic geography is not significant. Regarding control variables, the rural capital stock under the geographical adjacency matrix is significantly positive at the $1 \%$ level, indicating that the 
flow of neighboring rural capital stock will have a positive incentive effect on the province, while the rural human capital is significantly negative at the $5 \%$ level, indicating that the accumulation of human capital in neighboring rural areas in the province means the loss of human capital in neighboring provinces, which may have a negative effect on the agricultural economic growth of neighboring provinces. Under the comprehensive weight matrix of economic geography, rural capital stock, rural employees, and agricultural fiscal expenditure are significantly positive at the levels of $10 \%, 1 \%$, and $5 \%$, respectively, which have a positive effect on other spatially related provinces.

The total effect. The total effect of the matching coefficient of agricultural water and land resources under the geographic adjacency matrix is significantly positive at the level of $10 \%$, indicating that the geographic adjacency between provinces strengthens the spatial spillover effect of the agricultural water-land matching degree on the agricultural economic growth of the Yellow River Basin. It is not significant in the form of the comprehensive weight matrix of economic geography. It shows that the blessing of economic level and geographical distance cannot make the agricultural water-land matching situation have a significant impact on agricultural economic growth as a whole. Regarding control variables, under the geographical adjacency matrix, agricultural capital stock, total agricultural machinery power, and agricultural fiscal expenditure are significantly positive at the $5 \%$ or $1 \%$ level, and rural human capital is significantly negative at the $10 \%$ level. Under the comprehensive weight matrix of economic geography, rural capital stock, rural human capital, total power of agricultural machinery, and agricultural fiscal expenditure are significantly positive at the level of $5 \%$ or $1 \%$, and rural human capital is significantly positive under the comprehensive weight matrix of economic geography. Under the blessing of economic level and geographical distance, the higher the economic level, the more abundant human capital, which will accelerate the growth of agricultural economy and produce local effects and spillover effects on the province and spatially related provinces.

Further discussion. According to the above conclusion analysis, the agricultural economic growth of this province will have a negative effect on neighboring or spatially related provinces. The matching coefficient of agricultural water and land resources has no significant impact on the agricultural economic growth of this province, but it has a promoting effect on the agricultural economic growth of neighboring provinces-that is, a spatial spillover effect. However, under the comprehensive weight matrix of economic geography, the direct effect, indirect effect, and total effect of the matching coefficient of agricultural water and land resources are not significant. Based on the characteristics of water and land resources, the arrangement of agricultural production is more based on the production factors of the previous period - that is, the time lag and space lag of production factors or explanatory variables will also affect agricultural economic growth, Therefore, in order to further study the dynamic impact of the matching coefficient of agricultural water and land resources on the growth of agricultural economy in the Yellow River Basin, this paper estimates the dynamic spatial Durbin model under the geographical adjacency matrix and economic geospatial weight matrix, and gives its short-term effects and long-term effects, direct effects, and indirect effects.

\subsection{Estimation Results and Analysis of Dynamic Spatial Durbin Model}

By estimating the dynamic spatial Durbin model under the geographical adjacency matrix and the comprehensive weight matrix of economic geography, it is found that the spatial spillover effect of agricultural economic growth in a certain province on the agricultural economic growth of adjacent or spatially related provinces is significantly positive at the $1 \%$ level. At this time, the matching coefficient of agricultural water and land resources has a significant role in promoting the agricultural economic growth of the province. However, the matching coefficient of agricultural water and land resources has no significant effect on the agricultural economic growth of neighboring and spatially related provinces. Except that agricultural capital stock under the comprehensive matrix of economic geography is not significant, other control variables are basically significant. 
Analysis of short-term effects results. Tables 7 and 8, respectively, show the direct, indirect, and total effects of the matching coefficient of agricultural water and land resources on the agricultural economic growth of the Yellow River Basin in the short and long term under the geographical adjacency matrix and the economic geography comprehensive weight matrix.

Table 7. Decomposition of spatial effects under geographic adjacency matrix.

\begin{tabular}{|c|c|c|c|c|c|c|}
\hline Variables & $\begin{array}{l}\text { Short-Term } \\
\text { Direct Effect }\end{array}$ & $\begin{array}{l}\text { Short-Term } \\
\text { Indirect Effect }\end{array}$ & $\begin{array}{l}\text { Short-Term } \\
\text { Total Effect }\end{array}$ & $\begin{array}{l}\text { Long-Term } \\
\text { Direct Effect }\end{array}$ & $\begin{array}{l}\text { Long-Term } \\
\text { Indirect Effect }\end{array}$ & $\begin{array}{l}\text { Long-Term } \\
\text { Total Effect }\end{array}$ \\
\hline$m c$ & $\begin{array}{c}0.7333^{* * *} \\
(0.1475)\end{array}$ & $\begin{array}{c}0.4125 \\
(0.3011)\end{array}$ & $\begin{array}{c}1.1459^{* * *} \\
(0.2709)\end{array}$ & $\begin{array}{c}-1.7108^{* * *} \\
(0.3959)\end{array}$ & $\begin{array}{l}-0.4601 \\
(0.7227)\end{array}$ & $\begin{array}{c}-2.1709^{* * *} \\
(0.5679)\end{array}$ \\
\hline $\mathrm{ca}$ & $\begin{array}{c}-0.0274^{* *} \\
(0.0131)\end{array}$ & $\begin{array}{c}0.1371^{* * *} \\
(0.0174)\end{array}$ & $\begin{array}{c}0.1097^{* * *} \\
(0.0168)\end{array}$ & $\begin{array}{c}0.0958 * * \\
(0.0376)\end{array}$ & $\begin{array}{c}-0.3043^{* * *} \\
(0.04209)\end{array}$ & $\begin{array}{c}-0.2085^{* * *} \\
(0.0438)\end{array}$ \\
\hline$h c$ & $\begin{array}{c}7.8594^{* * *} \\
(0.9524)\end{array}$ & $\begin{array}{c}37.4497^{* * * *} \\
(2.2441)\end{array}$ & $\begin{array}{c}45.3092 * * * \\
(2.9945)\end{array}$ & $\begin{array}{c}-11.2918^{* * *} \\
(4.3836)\end{array}$ & $\begin{array}{c}-74.3818^{* * *} \\
(6.8494)\end{array}$ & $\begin{array}{c}-85.6737^{* * * *} \\
(10.7555)\end{array}$ \\
\hline$r w$ & $\begin{array}{c}-0.3287^{* *} \\
(0.1355)\end{array}$ & $\begin{array}{c}1.9408^{* * *} \\
(0.2452)\end{array}$ & $\begin{array}{c}1.6121^{* * *} \\
(0.2764)\end{array}$ & $\begin{array}{c}1.2217^{* * *} \\
(0.4343)\end{array}$ & $\begin{array}{c}-4.2627^{* * * *} \\
(0.5128)\end{array}$ & $\begin{array}{c}-3.0411^{* * *} \\
(0.5749)\end{array}$ \\
\hline$a m$ & $\begin{array}{c}-0.1765^{* * *} \\
(0.0345)\end{array}$ & $\begin{array}{c}-0.0938 * \\
(0.0529)\end{array}$ & $\begin{array}{c}-0.2749^{* * *} \\
(0.0461)\end{array}$ & $\begin{array}{c}0.4100^{* * * *} \\
(0.9101)\end{array}$ & $\begin{array}{c}0.1049 \\
(0.1184)\end{array}$ & $\begin{array}{c}0.5149 * * * \\
(0.0732)\end{array}$ \\
\hline$a e$ & $\begin{array}{c}-2.7202 * * * \\
(0.1918)\end{array}$ & $\begin{array}{c}-3.8920 * * * \\
(0.4622)\end{array}$ & $\begin{array}{c}-6.6121^{* * *} \\
(0.4966)\end{array}$ & $\begin{array}{c}5.8307^{* * * *} \\
(0.5903)\end{array}$ & $\begin{array}{c}6.6706^{* * * *} \\
(1.3675)\end{array}$ & $\begin{array}{c}12.5014^{* * *} \\
(1.6185)\end{array}$ \\
\hline
\end{tabular}

Note: $* * *, * *, *$ means passing the significance test at the levels of $1 \%, 5 \%$, and $10 \%$, respectively.

Table 8. Decomposition of Spatial Effects under the Comprehensive Weight Matrix of Economic Geography.

\begin{tabular}{|c|c|c|c|c|c|c|}
\hline Variables & $\begin{array}{l}\text { Short-Term } \\
\text { Direct Effect }\end{array}$ & $\begin{array}{l}\text { Short-Term } \\
\text { Indirect Effect }\end{array}$ & $\begin{array}{l}\text { Short-Term } \\
\text { Total Effect }\end{array}$ & $\begin{array}{l}\text { Long-Term } \\
\text { Direct Effect }\end{array}$ & $\begin{array}{l}\text { Long-Term } \\
\text { Indirect Effect }\end{array}$ & $\begin{array}{l}\text { Long-Term } \\
\text { Total Effect }\end{array}$ \\
\hline$m c$ & $\begin{array}{c}0.7182 * * * \\
(0.1281)\end{array}$ & $\begin{array}{l}-0.0775 \\
(0.1768)\end{array}$ & $\begin{array}{c}0.6507^{* * *} \\
(0.1911)\end{array}$ & $\begin{array}{c}-2.0749 * * * \\
(0.3839)\end{array}$ & $\begin{array}{c}0.6463 \\
(0.5672)\end{array}$ & $\begin{array}{c}-1.4286^{* * *} \\
(0.4964)\end{array}$ \\
\hline $\mathrm{ca}$ & $\begin{array}{c}0.0913^{* * *} \\
(0.0111)\end{array}$ & $\begin{array}{l}-0.0123 \\
(0.0244)\end{array}$ & $\begin{array}{c}0.0790^{* * *} \\
(0.0233)\end{array}$ & $\begin{array}{c}-0.2603^{* * *} \\
(0.0351)\end{array}$ & $\begin{array}{c}0.0882 \\
(0.0704)\end{array}$ & $\begin{array}{c}-0.1722^{* * *} \\
(0.0567)\end{array}$ \\
\hline$h c$ & $\begin{array}{c}17.6015^{* * *} \\
(0.8161)\end{array}$ & $\begin{array}{c}34.7180 * * * \\
(3.3345)\end{array}$ & $\begin{array}{c}52.3196^{* * *} \\
(4.0033)\end{array}$ & $\begin{array}{c}-42.5076^{* * *} \\
(4.1825)\end{array}$ & $\begin{array}{c}-71.7096^{* * *} \\
(16.4003)\end{array}$ & $\begin{array}{c}-114.2172^{* * *} \\
(20.3246)\end{array}$ \\
\hline$r w$ & $\begin{array}{c}0.5766^{* * *} \\
(0.1279)\end{array}$ & $\begin{array}{c}2.0759 * * * \\
(0.2905)\end{array}$ & $\begin{array}{c}2.6525^{* * *} \\
(0.3369)\end{array}$ & $\begin{array}{c}-1.1919^{* * * *} \\
(0.4458)\end{array}$ & $\begin{array}{c}-4.5815^{* * *} \\
(0.8657)\end{array}$ & $\begin{array}{c}-5.7735^{* * *} \\
(1.0850)\end{array}$ \\
\hline$a m$ & $\begin{array}{l}-0.0126 \\
(0.0258)\end{array}$ & $\begin{array}{c}-0.3915^{* * *} \\
(0.0534)\end{array}$ & $\begin{array}{c}-0.4041^{* * *} \\
(0.0591)\end{array}$ & $\begin{array}{l}-0.0470 \\
(0.0896)\end{array}$ & $\begin{array}{c}0.9232 * * * \\
(0.1362)\end{array}$ & $\begin{array}{c}0.8761^{* * *} \\
(0.1589)\end{array}$ \\
\hline$a e$ & $\begin{array}{c}-2.3447^{* * *} \\
(0.1867)\end{array}$ & $\begin{array}{l}-5.2183^{* * *} \\
(0.6009)\end{array}$ & $\begin{array}{c}-7.5630^{* * *} \\
(0.6922)\end{array}$ & $\begin{array}{c}5.5288^{* * *} \\
(0.8068)\end{array}$ & $\begin{array}{c}10.9628^{* * *} \\
(2.3142)\end{array}$ & $\begin{array}{c}16.4916^{* * *} \\
(2.9246)\end{array}$ \\
\hline
\end{tabular}

Note: ${ }^{* * *}$ means passing the significance test at the levels of $1 \%$, respectively.

Short-term direct effects. Under the two matrix forms, the matching status of agricultural water and land resources is significantly positive for the province's agricultural economic growth at the $1 \%$ level. It shows that the current situation of water and land resources will have an impact on agricultural production. If the short-term unit of arable land is short of water resources and agricultural water is scarce, agricultural production and income will decrease [43]. If the short-term unit of arable land is rich in water resources and agricultural water is abundant, agricultural production and income will increase. This result shows the reasonable existence of the direct-action mechanism of the agricultural water-land matching coefficient in the short term. Regarding the short-term direct effects of other control variables, basically all are significant and positive, except that the total power of agricultural machinery under the comprehensive economic geography matrix has no significant impact, indicating that in the short term, it is restricted by the level of economic development. Agricultural machinery input exceeds output; the increase in agricultural income is affected by costs in the short-term, though the role is not clear. 
Short-term indirect effects. The agricultural water-land matching of adjacent or spatially related provinces has no significant effect on the agricultural economic growth of the province. The short-term indirect effects are smaller than the short-term direct effects, and the short-term indirect effects are negative under the comprehensive matrix of economic geography weights. Regarding the short-term indirect effects of the control variables, under the geographical adjacency matrix, the agricultural capital stock, agricultural human capital, and rural employees in adjacent or spatially related provinces have a significant positive effect on the agricultural economic growth of the province, while the total power of agricultural machinery and agricultural fiscal expenditures are significantly negative. Under the comprehensive weight matrix of economic geography, the agricultural capital stock of neighboring or spatially related provinces is not significant to the province's agricultural economic growth, and the other control variables are consistent in significance.

Short-term total effects. Comprehensively considering the spillover effects within and between regions, it is found that under the two matrix forms, the total effect of the matching coefficient of agricultural water and land resources on the agricultural economic growth of the Yellow River Basin is significantly positive, and the short-term total effect under the geographic adjacency matrix is significantly greater than the short-term total effect under the comprehensive weight matrix of economic geography. It shows that the impact of the matching coefficient of agricultural water and land resources on agricultural economic growth in the short term is more affected by geographic proximity than economic geographic distance. Regarding other control variables, the estimation results under the two matrices are consistent. The total effect of agricultural capital stock, agricultural human capital, and rural employment population on the agricultural economic growth of the Yellow River Basin is significantly positive, and the total power of agricultural machinery and agricultural fiscal expenditure are significantly negative. The reason is that they are affected by the short-term input-output ratio.

\section{Analysis of Long-Term Effects}

Long-term direct effects. Under the two matrix forms, the matching status of agricultural water and land resources is significantly negative for the province's agricultural economic growth at the $1 \%$ level. This shows that in the long run, the matching of agricultural water and land resources will have a restraining effect on agricultural economic growth. It shows that if the matching of agricultural water and land resources is not alleviated for a long time, and the water resources per unit of arable land continue to decline, it will have an adverse impact on the agricultural economic growth of the province. Regarding the long-term direct effects of other control variables, under the geographical adjacency matrix, agricultural capital stock, rural employees, total power of agricultural machinery, and agricultural fiscal expenditures are significantly positive for the province's agricultural economic growth and rural human capital is significantly negative. The comprehensive economic and geographic weight matrix. Under the circumstances, agricultural capital stock, rural human capital, and rural employees are significantly negative; the total power of agricultural machinery is not significant; and agricultural fiscal expenditures are significantly positive.

Long-term indirect effects. In the long run, the agricultural water-land matching coefficient of adjacent or spatially related provinces have no significant effect on the agricultural economic growth of the province. It shows that the long-term indirect effect mechanism is not robust. Regarding the long-term indirect effects of other control variables, under the geographical adjacency matrix, agricultural capital stock, rural human capital, and rural employees are significantly negative; the total power of agricultural machinery is not significant; and agricultural fiscal expenditures are significantly positive. Under the comprehensive weight matrix of economic geography, rural human capital and rural employees are significantly negative, the total power of agricultural machinery and agricultural fiscal expenditure are significantly positive, and agricultural capital stock is not significant in the long run. 
Long-term total effects. From a long-term perspective, the direct effect of the matching coefficient of agricultural water and land resources on the agricultural economic growth of the Yellow River Basin is significantly smaller than the indirect effect. Since the long-term direct effect is significantly negative, the total effect is negative, which is significant at the $1 \%$ level. The two matrix situations are consistent. It shows that whether it is in neighboring provinces or restricted by the level of economic development and geographical distance, the matching degree of long-term agricultural water and land resources has a negative spillover to the agricultural economic growth within and between regions. To a certain extent, it also shows that the Yellow River Basin is a resource-intensive, water-scarce area, and water resources are in short supply. The water resources per unit of arable land have not been alleviated for a long time, and the utilization rate of water resources is limited. Therefore, the impact on agricultural economic growth is limited or even restrictive. The other control variables, agricultural capital stock, rural human capital, and rural employees are all significantly negative, while the total power of agricultural machinery and agricultural fiscal expenditure are significantly positive.

Further discussion. According to the above analysis, first, this article believes that the agricultural economic growths of the provinces in the Yellow River Basin are mutually influenced by each other. The agricultural economic growth of a region will effectively promote the agricultural economic development of its neighboring provinces or provinces with high spatial correlation, which produce a demonstration effect and imitation effect [44] Second, the matching degree of agricultural water and land resources has a positive impact on the agricultural economy of the province. The higher the matching degree of water and land resources, the better the level of agricultural production and the faster the growth of agricultural economy. At the same time, the geographical proximity and spatial dependence of the province's agricultural water and land matching will also generate positive incentives for agricultural economic growth in the province [45-47]. Third, in the short term, the better the matching of agricultural water and land resources, the better the agricultural production conditions - that is, the more water resources per unit of arable land in the current period, the higher the agricultural output, and the more effectively the development of agricultural economy can be promoted. Fourth, from a long-term perspective, water resources in the Yellow River Basin have been relatively scarce. Although the area of arable land has increased slightly, the overall decreasing trend has not changed. The total amount of water resources has also failed to increase effectively, resulting in a long-term shortage of agricultural water consumption per unit of area land. It has a certain inhibitory effect on the growth of agricultural economy. Under the premise of limited water resources, it is necessary to strictly control water and optimize the allocation of water resources [48,49]; and explore the efficient and dynamic implementation of the collaborative negotiation and water diversion mechanism in the upper, middle, and lower reaches of the Yellow River [50].

\section{Conclusions and Policy Recommendations}

\subsection{Main Conclusions}

This paper utilizes the panel data of nine provinces in the Yellow River Basin from 2000 to 2019. First, we measured the agricultural water and land resources matching coefficient and the agricultural water and land resources equivalent coefficient; then, we used Moran's I index to analyze the global spatial autocorrelation and local autocorrelation of the agricultural economic growth and the matching coefficient of agricultural water and land resources in the Yellow River Basin; finally, the static and dynamic spatial Durbin model was used to analyze the direct and indirect effects, long-term effects, and short-term effects of the matching coefficient of agricultural water and land resources in the agricultural economic growth of the Yellow River Basin. The main conclusions are as follows:

First, according to the calculation of the average water and land resources matching coefficient and the agricultural water and land resources equivalent coefficient of the provinces in the Yellow River Basin from 2000 to 2019, it can be seen that Shanxi, Inner Mongolia, Shandong, Gansu, and Ningxia are areas with relatively short water resources, 
and Shaanxi is a region with relatively balanced water and land resources. Henan, Sichuan, and Qinghai are areas with relatively scarce land resources. It should be pointed out that Sichuan and Qinghai are relatively rich in water resources. It can be seen that the overall matching of agricultural water and land resources in the Yellow River Basin is poor, especially the lack of water resources.

Second, according to the global and local Moran's I index, the agricultural economic growth of the Yellow River Basin and the matching coefficient of agricultural water and land resources show a significant positive spatial correlation; in 2000, 2006, 2013, and 2019, the local spatial autocorrelation was highly robust. Regarding the local autocorrelation of agricultural economic growth, Shandong and Henan belong to the high-high agglomeration type; Shanxi and Qinghai belong to the low-high agglomeration type; Inner Mongolia, Shaanxi, Gansu, and Ningxia belong to the low-low agglomeration type; and Sichuan belongs to the high-low aggregation type. Regarding the degree and structure of the matching coefficient of agricultural water and land resources, Sichuan and Qinghai, which are rich in water resources per unit of arable land, belong to the high-high agglomeration type; Gansu has low-high agglomeration type; and Shanxi, Inner Mongolia, Shandong, Henan, Shaanxi, and Ningxia-where water resources per unit of arable land are lackingbelong to the low-low agglomeration type.

Third, the static spatial Durbin model estimation results under the geographical adjacency matrix show that the matching of agricultural water and land resources has no significant direct effect on the agricultural economic growth of the province, but the indirect effect of matching the agricultural water and land resources of the geographically adjacent provinces on the agricultural economic growth of the province is significantly positive. The total effect space spillover within and between regions is significantly positive.

Fourth, the results of the dynamic spatial Durbin model under the two matrix forms show that the short-term direct effect of matching the agricultural water and land resources on agricultural economic growth is significantly positive, the short-term indirect effect is not significant, and the short-term direct effect is greater than the short-term indirect effect; so, the short-term total effect is significantly positive, indicating that the matching coefficient of agricultural water and land resources in the short-term promotes the agricultural economic growth of this province; the long-term direct effect is significantly negative, the long-term indirect effect is not significant, and the long-term direct effect is significantly smaller than the long-term indirect effect; so, the long-term total effect is significantly negative. In the long run, agricultural water consumption per unit of arable land has been in short supply for a long time, and the matching of agricultural water and land is poor, which has a restrictive effect on agricultural economic growth.

\subsection{Policy Recommendations}

The above conclusions have profound policy implications for the reasonable and sustainable matching of agricultural water and land resources in the Yellow River Basin and promoting the high-quality development of the agricultural economy in the Yellow River Basin (the specific recommendations can be seen in the Appendix A, Table A3):

Short-term effect recommendations. Regarding short-term direct effects, all regions should continue to strengthen land resource protection and cultivated land red line management, and strictly manage water resources. Regarding short-term indirect effects, all provinces should coordinate and improve the water rights transfer and compensation system and explore the linkage mechanism of the regulation of water use indicators and land indicators. Regarding short-term total effects, local agricultural departments should strengthen the protection of land and water ecology in the Yellow River Basin. All should strive to prevent and control agricultural water and land pollution, improve the selfpurification ability of soil and water environment of farmland, and reduce water quality water shortage and cropland reduction caused by human causes. The governments of neighboring provinces should strengthen the coordinated distribution of water and land resources and jointly promote the efficient use of water resources. The government should 
use direct regulatory policy tools, institutional policy tools, and social policy tools. In the implementation process, attention must be paid to the framework of regional agreements, emphasizing fairness and ensuring sufficient information disclosure.

Long-term effect recommendations. Regarding long-term direct effects, relevant government departments should adhere to the system first, provide legislative protection, and insist on determining land and production by water. The three-pronged approach of economic, legal, and administrative measures shall guide the transformation of agricultural production methods and promote the intensive transformation of agricultural water-use methods. Regarding long-term indirect effects, The Yellow River Water Conservancy Commission should urge all provinces to establish water ecological corridors to strengthen the connectivity, integration, and improvement of rural water systems in various provinces and river basins. The government should enrich the water resources network system and strengthen the construction of flood containment and flood storage projects to maximize the rational distribution of water and land resources across time and space and reduce the negative impact of water and land resource mismatch between provinces. Regarding long-term total effects, all regions and departments should explore the efficient and dynamic implementation of the mechanism of collaborative negotiation and water division in the upper, middle, and lower reaches of the Yellow River. They should improve the water resources management and distribution system, improve the big data full-time and whole-basin supervision system, monitor in real-time, and perform effective dynamic management. Relevant departments regularly analyze and flexibly adjust the water resource allocation plan to maximize the balance of water use and water conservation in agriculture in various regions. The government should use economic and legal tools, social policy tools, and technical policy tools; in the implementation process, it should pay attention to the coordination between regions and control the cost of trial and error and implementation.

Lastly, this paper focuses on the matching status of water and soil resources in the Yellow River Basin, and the characteristics of space-time matching. The problem is mainly studied from a macro perspective, where there are certain limitations. Due to the difficulty in obtaining data and professional limitations, this paper lacks the analysis of the impact of agricultural water use structure and soil characteristics within the region-including planting structure, irrigation method, soil type, and soil quality — on the matching of water and land resources. That is to say, the reason for the change of the matching characteristics of water and land resources is limited, and further research needs to be carried out from a microscopic perspective.

Author Contributions: Conceptualization, Y.Z.; methodology, Y.Z.; writing—original draft preparation, Y.Z.; writing-review and editing, Y.Z., W.L., H.L., Z.W., B.Z. and K.Z. All authors have read and agreed to the published version of the manuscript.

Funding: This research received no external funding.

Institutional Review Board Statement: Not applicable.

Informed Consent Statement: Not applicable.

Data Availability Statement: Not applicable.

Conflicts of Interest: The authors declare that there is no conflict of interest. 


\section{Appendix A}

Table A1. Comparative analysis of agricultural water and land resources matching calculation method.

\begin{tabular}{|c|c|c|c|c|}
\hline $\begin{array}{c}\text { Agricultural Water } \\
\text { and Land Resources } \\
\text { Matching } \\
\text { Calculation Method }\end{array}$ & Definition & Advantages & Disadvantages & $\begin{array}{c}\text { Representative } \\
\text { Scholars }\end{array}$ \\
\hline $\begin{array}{l}\text { Agricultural Water and } \\
\text { Land Resources } \\
\text { Matching } \\
\text { Coefficient Method }\end{array}$ & $\begin{array}{l}\text { The temporal and spatial } \\
\text { matching proportional } \\
\text { relationship between } \\
\text { agricultural available water } \\
\text { resources and cultivated land } \\
\text { resources, using the amount } \\
\text { of water resources per unit of } \\
\text { cultivated land as the } \\
\text { calculation rule }\end{array}$ & $\begin{array}{l}\text { It has strong data } \\
\text { availability, mature } \\
\text { methods, and } \\
\text { strong operability }\end{array}$ & $\begin{array}{l}\text { It may overestimate the } \\
\text { degree of agricultural } \\
\text { water and land } \\
\text { matching and fail to } \\
\text { identify the uneven } \\
\text { distribution of water } \\
\text { and land resources } \\
\text { within the region }\end{array}$ & Liu, Y.S., et al. \\
\hline $\begin{array}{l}\text { Generalized } \\
\text { Agricultural Soil and } \\
\text { Water Resources } \\
\text { Matching } \\
\text { Coefficient Method }\end{array}$ & $\begin{array}{l}\text { The proportional relationship } \\
\text { between the matching of } \\
\text { irrigation "blue water" and } \\
\text { precipitation "green water" } \\
\text { and cultivated land area }\end{array}$ & $\begin{array}{l}\text { It emphasizes the } \\
\text { contribution of } \\
\text { regional precipitation } \\
\text { "green water" to } \\
\text { agricultural } \\
\text { production }\end{array}$ & $\begin{array}{l}\text { It fails to identify the } \\
\text { uneven distribution of } \\
\text { land and water } \\
\text { resources within } \\
\text { a region }\end{array}$ & $\begin{array}{l}\text { Gao, Y., et al.; } \\
\text { Xu, C.X., et al.; } \\
\text { Liu, D.; Liu, C.L.; } \\
\text { FU, Q., et al. }\end{array}$ \\
\hline Gini coefficient method & $\begin{array}{l}\text { The combination composed } \\
\text { of multiple subregions is } \\
\text { regarded as a whole, which } \\
\text { is used to quantify the } \\
\text { uneven distribution of water } \\
\text { and land resources among } \\
\text { the subregions }\end{array}$ & $\begin{array}{l}\text { It helps to identify } \\
\text { imbalances in the } \\
\text { matching of land and } \\
\text { water resources }\end{array}$ & $\begin{array}{l}\text { It is impossible to } \\
\text { quantitatively analyze } \\
\text { the matching status of } \\
\text { the overall water and } \\
\text { land resources in a } \\
\text { certain area }\end{array}$ & $\begin{array}{c}\text { Masaki, Y.; } \\
\text { Hanasaki, N.; } \\
\text { Takahashi, K., et al. }\end{array}$ \\
\hline $\begin{array}{l}\text { Malmquist } \\
\text { DEA method }\end{array}$ & $\begin{array}{l}\text { The DEA-based water and } \\
\text { soil resources matching } \\
\text { model uses water resources } \\
\text { and cultivated land resources } \\
\text { as input indicators and } \\
\text { agricultural output as output } \\
\text { indicators to analyze the } \\
\text { matching characteristics of } \\
\text { water and soil resources }\end{array}$ & $\begin{array}{l}\text { It pays attention to } \\
\text { the degree of resource } \\
\text { input and output and } \\
\text { the efficiency of water } \\
\text { and land } \\
\text { resource utilization }\end{array}$ & $\begin{array}{l}\text { It uses water resources } \\
\text { and cultivated land } \\
\text { resources as model } \\
\text { inputs cannot fully } \\
\text { reflect the influencing } \\
\text { factors of agricultural } \\
\text { output value }\end{array}$ & $\begin{array}{l}\text { Xu, N.; Zhang, J.; } \\
\text { Zhang, R.Z., et al. }\end{array}$ \\
\hline $\begin{array}{l}\text { Comprehensive use } \\
\text { method of matching } \\
\text { coefficient of water and } \\
\text { land resources and } \\
\text { Gini coefficient }\end{array}$ & $\begin{array}{l}\text { By calculating the matching } \\
\text { coefficient of water and land } \\
\text { resources, the matching } \\
\text { status of water and land } \\
\text { resources in a certain area } \\
\text { can be obtained, and then the } \\
\text { Gini coefficient can be } \\
\text { calculated to further analyze } \\
\text { the uneven distribution of } \\
\text { water and soil resources } \\
\text { within the region }\end{array}$ & $\begin{array}{l}\text { It consider the } \\
\text { relationship between } \\
\text { the amount of water } \\
\text { resources and the } \\
\text { amount of cultivated } \\
\text { land in the region, as } \\
\text { well as the balance of } \\
\text { distribution in the } \\
\text { region }\end{array}$ & $\begin{array}{l}\text { It ignore the } \\
\text { characteristics of water } \\
\text { resources in } \\
\text { different regions }\end{array}$ & $\begin{array}{l}\text { Li, T.X.; Fu, Q.; } \\
\text { Meng, F.X. }\end{array}$ \\
\hline
\end{tabular}


Table A2. Explanation of related indicators.

\begin{tabular}{|c|c|c|}
\hline $\begin{array}{l}\text { First-Level } \\
\text { Indicator }\end{array}$ & $\begin{array}{l}\text { Second-Level } \\
\text { Indicator }\end{array}$ & Related Explanation \\
\hline $\begin{array}{l}\text { Agricultural } \\
\text { economic } \\
\text { growth }\end{array}$ & $\begin{array}{l}\text { Gross output value of } \\
\text { agriculture, forestry, } \\
\text { animal husbandry, } \\
\text { and fishery }\end{array}$ & $\begin{array}{l}\text { This paper selects the total output value of agriculture, forestry, animal husbandry, } \\
\text { and fishery to measure the agricultural economic growth of the provinces in the } \\
\text { Yellow River Basin. In order to eliminate the impact of price changes, the regional } \\
\text { GDP is set at a constant price in 2000, and then calculate the actual total output value } \\
\text { of agriculture, forestry, animal husbandry, and fishery in each province based on the } \\
\text { total output value index of agriculture, forestry, animal husbandry, and fishery. }\end{array}$ \\
\hline $\begin{array}{l}\text { Matching of } \\
\text { water and } \\
\text { land resources }\end{array}$ & $\begin{array}{l}\text { Agricultural water and } \\
\text { land resources } \\
\text { matching coefficient }\end{array}$ & $\begin{array}{l}\text { The matching coefficient of agricultural water and land resources is used to measure } \\
\text { the temporal and spatial matching degree of water resources and land resources in } \\
\text { agricultural development. The more water resources per unit land area, the higher the } \\
\text { matching degree, and the better the agricultural production conditions. Therefore, this } \\
\text { paper adopts the unit arable land area-total water resources method to measure the } \\
\text { matching coefficient of agricultural water and land resources. }\end{array}$ \\
\hline Capital & Capital stock & $\begin{array}{l}\text { This article selects the capital stock of each city from } 2000 \text { to } 2019 \text { and draws on } \\
\text { Zhang, J.'s interprovincial capital stock method for calculation. The adjusted } \\
\text { calculation formula is as follows: } c a_{i t}=c a_{i t-1}\left(1-\delta_{i t}\right)+I_{i t} \text {, where } c a_{i t} \text { is the rural } \\
\text { capital stock and } c a_{i t-1} \text { is the rural capital stock of the previous year; } I_{i t} \text { is the total } \\
\text { fixed capital investment in rural areas; } i \text { represents the province } i ; t \text { represents the year } \\
\qquad t ; \delta_{i t} \text { is the depreciation rate, which is } 9.6 \% \text {. }\end{array}$ \\
\hline Labor force & Rural workers & $\begin{array}{l}\text { The labor force chooses the rural workers index, which is measured by the total } \\
\text { number of people engaged in agriculture, forestry, animal husbandry, and fishery }\end{array}$ \\
\hline Human capital & Rural human capital & $\begin{array}{l}\text { In this paper, rural human capital is measured by the average years of education; } \\
\text { specifically, } 6 \text { years for elementary school, } 9 \text { years for junior high school, } 12 \text { years for } \\
\text { high school, and } 16 \text { years for junior college and above. Its specific calculation formula } \\
\text { is as follows: } h c=\left[\left(\sum \text { Number of people with primary school education } \times 6+\right.\right. \\
\left(\sum \text { Number of people with junior high school education } \times 9\right)+\left(\sum \text { Number of people }\right. \\
\text { with high school education } \times 12)+\sum \text { Number of people with college education and } \\
\text { above } \times 16)] / \text { total number of employees. }\end{array}$ \\
\hline $\begin{array}{l}\text { Technological } \\
\text { innovation }\end{array}$ & $\begin{array}{l}\text { Total power of } \\
\text { agricultural machinery }\end{array}$ & $\begin{array}{l}\text { Agricultural mechanization is an important symbol that reflects the level of } \\
\text { agricultural technology; the total power of agricultural machinery can be selected to } \\
\text { represent the degree of agricultural technology innovation }\end{array}$ \\
\hline $\begin{array}{l}\text { Government } \\
\text { spending }\end{array}$ & $\begin{array}{l}\text { Agricultural fiscal } \\
\text { expenditure }\end{array}$ & $\begin{array}{l}\text { The government's support and subsidies for agriculture are an important source of } \\
\text { funds for agricultural development; so, it is necessary to consider the government's } \\
\text { financial expenditure on agriculture. We specifically selected the financial expenditure } \\
\text { for agriculture, forestry, and water affairs. }\end{array}$ \\
\hline
\end{tabular}

Table A3. Policy recommendations and implementation risk.

\begin{tabular}{ccccc}
\hline & Possible Results & $\begin{array}{c}\text { Policy Tool } \\
\text { Selection }\end{array}$ & Policy Recommendations & Implementation Risk \\
\hline $\begin{array}{c}\text { Short-term } \\
\text { direct effects }\end{array}$ & $\begin{array}{c}\text { significantly } \\
\text { positive }\end{array}$ & $\begin{array}{c}\text { Direct } \\
\text { regulatory } \\
\text { policy tools }\end{array}$ & $\begin{array}{c}\text { All regions should continue to strengthen } \\
\text { land resource protection and cultivated } \\
\text { land red line management, and strictly } \\
\text { manage water resources. }\end{array}$ & $\begin{array}{c}\text { Inflexibility, dynamic } \\
\text { inefficiency, it may cost } \\
\text { social welfare. }\end{array}$ \\
$\begin{array}{c}\text { Short-term } \\
\text { indirect } \\
\text { effects }\end{array}$ & $\begin{array}{c}\text { significantly nega- } \\
\text { tive(economic } \\
\text { geographical } \\
\text { distance) }\end{array}$ & $\begin{array}{c}\text { Institutional } \\
\text { policy tools }\end{array}$ & $\begin{array}{c}\text { All provinces should coordinate and } \\
\text { improve the water rights transfer and } \\
\text { compensation system, and explore the } \\
\text { linkage mechanism of the regulation of } \\
\text { water use indicators and land indicators. }\end{array}$ & $\begin{array}{c}\text { The cost of damage and } \\
\text { vested interests must be } \\
\text { considered under the } \\
\text { framework of regional } \\
\text { agreements. The cost of } \\
\text { damage is too high and there } \\
\text { is a lack of fairness. }\end{array}$ \\
\hline
\end{tabular}


Table A3. Cont.

\section{Possible Results Policy Tool \\ Selection}

significantly positive(geographical distance is

Short-term total effects stronger than economical geographic distance)
Social

policy tools

\section{Policy Recommendations}

Local agricultural departments should strengthen the protection of land and water ecology in the Yellow River Basin. They should strictly prevent and control agricultural water and land pollution, improve the self-purification ability of soil and water environment of farmland, and reduce water shortage and cropland reduction caused by humans. The governments of neighboring provinces should strengthen the coordinated distribution of water and land resources and jointly promote the efficient use of water resources.
Implementation Risk

Under the framework of regional agreements, it is necessary to ensure that information is open and sufficient, and the time lag for effectiveness is long.
Relevant government departments should adhere to the system first, provide legislative protection, and insist on determining land and production by water. The three-pronged approach of economic, legal, and administrative measures shall guide the transformation of agricultural production methods and promote the transformation of agricultural water use methods to intensive transformation.
Market supervision and law enforcement are difficult; it is difficult to form a unified measurement standard, and the cost of trial and error is high.
The Yellow River Water Conservancy

Commission should urge all provinces to establish water ecological corridors to

strengthen the connectivity, integration, and improvement of rural water systems in various provinces and river basins. The government should enrich the water resources network system and strengthen the construction of flood containment and flood storage projects to maximize the rational distribution of water and land resources across time and space, and reduce the negative impact of water and land resource mismatch between provinces.
Coordination between local governments.
All regions and departments should explore the efficient and dynamic implementation of the mechanism of collaborative negotiation and water division in the upper, middle, and lower reaches of the Yellow River. They should improve the water resources management and distribution system, improve the big data full-time and whole-basin supervision system, monitor in real time, and perform effective dynamic management. Relevant departments regularly analyze and flexibly adjust the water resource allocation plan to maximize the balance of water use and water conservation in agriculture in
Long-term total effects

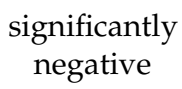

Technology policy tools
Implementation costs are too high. various regions. 


\section{References}

1. Fang, L.N.; Yin, C.B.; Fang, Z. The promotion path of high-quality agricultural development in the Yellow River Basin. China Agric. Resour. Reg. 2021, 12, 16-22.

2. Lal, R.; Griffin, M.; Apt, J. Ecology. Managing soil carbon. Science 2004, 304, 393. [CrossRef] [PubMed]

3. Fei, W.; Mu, X.; Li, R. Co-evolution of soil and water conservation policy and human-environment linkages in the yellow river basin since 1949. Sci. Total Environ. 2015, 508, 166-177.

4. Zhu, X.M.; Ren, M.E. The formation process and remediation countermeasures of the Chinese Loess Plateau. Chin. Hist. Geotheory Ser. 1991, 4, 1-14.

5. Shan, 1.; $\mathrm{Xu}, \mathrm{B} . \mathrm{C}$. Discussion on issues related to returning farmland to forest (grass) on the Loess Plateau in the new era. Bull. Soil Water Conserv. 2019, 6, 295-297.

6. Zhao, W. Sediment of the Yellow River; Yellow River Conservancy Press: Zhengzhou, China, 1996; pp. 35-55, 796-798. (In Chinese)

7. Walling, D.E.; Webb, B.W. Erosion and sediment yield: A global overview. In Erosion and Regional Perspectives; Walling, D.E., Webb, B., Eds.; IAHS Press: Wallingford, UK, 1996; pp. 3-19.

8. Jiang, Q.X.; Fu, Q.; Wang, Z.L. Spatial matching pattern of water and land resources in the Sanjiang Plain. J. Nat. Resour. 2011, 26, 270-277.

9. Meng, Q. Soil and Water Conservation of Loess Plateau; Yellow River Conservancy Press: Zhengzhou, China, 1997; pp. 509-522. (In Chinese)

10. Hua, J.; Sheng, X.H. Measurement and spatiotemporal analysis of water and soil resources damping effect on grain production in nine provinces along the Yellow River. China Popul. Resour. Environ. 2021, 8, 148-156.

11. Hu, S.H.; Cheng, Q.H.; Zhang, G.H. Analysis on the utilization trend of water resources in the Yellow River Basin. Chin. J. Water Resour. Water Eng. 2012, 2, 113-115.

12. Liu, C.M. Some Understandings of Ecological Protection and High-quality Development in the Yellow River Basin. People's Yellow River 2019, 10, 158

13. Liu, J.; Mei, X.R.; Lian, Y.Y. Research on the optimal allocation of water and soil resources in the high-quality development of agriculture in the Yellow River Basin. Agric. Resour. Zoning China 2021, 11, 1-18.

14. Ministry of Agriculture and Rural Affairs. 2019 National Cultivated Land Quality Grade Bulletin. China Compr. Agric. Dev. 2020, 6, 6-12.

15. Wang, H.L.; Qin, T.L.; Yan, D.H. The development trend, crux and comprehensive response of water problems in the Yellow River Basin. People's Yellow River 2020, 9, 107-111.

16. Liu, Y.S.; Gan, H.; Zhang, F.G. The matching pattern of agricultural water and land resources in Northeast China. Acta Geogr. Sin. 2006, 61, 847-854.

17. Yao, H.J.; Zhou, H.F.; Su, F.C. Looking at the water problems in Central Asia from the matching relationship of water and land resource. Arid Zone Res. 2013, 30, 391-395.

18. Ji, Y.; Yang, Q.; Lin, A.W. Spatial-temporal differentiation characteristics of water and landresource structure and productivity in Jianghan Plain. Bull. Landand Water Conserv. 2016, 36, 320-325.

19. Xu, C.X.; Lin, J.T.; Song, M. Water and land matching, spatial effects and regional agricultural economic growth-Based on the empirical analysis of China 2003-2013. China Popul. Resour. Environ. 2016, 26, 153-158.

20. Wen, Q.; Meng, T.X.; Yun, Y.H. Spatial and temporal differentiation and matching pattern of agricultural water and land resources in Henan Province. Res. Landand Water Conserv. 2017, 24, 233-239.

21. Huang, F.H.; Huang, B.S.; Qiu, J. Research on spatial equilibrium of water resources in Guangdong Province based on equilibrium coefficients. J. Sun Yat-sen Univ. 2021, 61, 1-8.

22. Xu, N.; Zhang, J.; Zhang, R.Z. Research on the matching characteristics of agricultural water and land resources based on DEA-Taking 5 watersheds in Gansu Province as an example. China Agric. Resour. Reg. 2020, 41, 277-285.

23. Wang, J.Y.; Xin, L.J.; Da, L.F. Changes in the matching pattern of agricultural water and land resources in typical mountainous areas in China: Taking Taihang Mountain, Hengduan Mountain, and Guizhou-Guizhou Karst Mountain as examples. Geogr. Res. 2020, 39, 1879-1891.

24. Gao, Y.; Qi, X.B.; Li, P. Spatial and temporal matching characteristics of agricultural water and land resources in the Yellow River Basin. J. Irrig. Drainage. 2021, 40, 1-6.

25. Zheng, J.Y.; Zhao, X.N.; Cao, X.C. Study on spatial-temporal matching pattern of agricultural water and land resources in Hetao irrigation district. Res. Soil Water Conserv. 2015, 3, 132-136.

26. Nan, J.Q.; Wang, J.L.; Tao, G.T. Matching patterns of agricultural soil and water resources in northwest arid area. J. Irrig. Drain. 2015, 34, 41-45.

27. Liu, D.; Liu, C.L.; Fu, Q. Construction and application of a refined index for measuring the regional matching characteristics between water and land resources. Ecol. Indic. 2018, 91, 203-211. [CrossRef]

28. $\mathrm{Xu}, \mathrm{N}$.; Zhang, J.; Zhang, R.Z. Research on the utilization efficiency and matching characteristics of agricultural water and land resources in Gansu inland river basin based on Malmquist DEA. China Agric. Sci. Technol. Rev. 2020, $22,115-122$.

29. Wu, Y.Z.; Bao, H.J. Regional Gini coefficient and its application in matching analysis of regional water and land resources. $J$. Landand Water Conserv. 2003, 5, 123-125. 
30. Zhang, X.T.; Yu, F.W. Analysis on the matching status of economic development and water resources in the Yellow River Basin. China Popul. Resour. Environ. 2012, 22, 1-6.

31. Peng, L.; Deng, W.; Tan, J. The matching relationship between the utilization of water and land resources and economic growth in the Hengduan Mountains. Acta Geogr. Sin. 2020, 75, 1996-2008.

32. Fan, H.L.; Fu, W.G. my country's agricultural water and landresource matching and agricultural economic growth from the perspective of water footprint: Taking the Yangtze River Economic Belt as an example. China Agric. Resour. Reg. Plan. 2020, 41, 193-203.

33. Li, X.Y.; Hao, J.M.; Chen, A.Q. Spatial-temporal matching pattern and evaluation of agricultural water and land resources in Shandong Province. J. China Agric. Univ. 2020, 25, 1-11.

34. Geng, Q.; Wu, P.; Zhao, X. A framework of indicator system for zoning of agricultural water and land resources utilization: A case study of Bayan Nur, Inner Mongolia. Ecol. Indic. 2014, 40, 43-50. [CrossRef]

35. Song, M.L.; Wang, S.H.; Huang, B. Spatial measurement of industrial agglomeration and diffusion in six provinces in central China. Geogr. Res. 2012, 30, 534-544.

36. Anselin, L. Local Indicators of Spatial Association: LISA. Geogr. Anal. 1995, 27, 93-115. [CrossRef]

37. Bai, J.H.; Wang, Y.; Jiang, F.X.; Li, J. The flow of R\&D factors, spatial knowledge spillover and economic growth. Econ. Res. 2017, 52, 109-123.

38. Ji, Y.; Xue, J.; Zhong, K. Does Environmental Regulation Promote Industrial Green Technology Progress? Empirical Evidence from China with a Heterogeneity Analysis. Int. J. Environ. Res. Public Health 2022, 19, 484. [CrossRef] [PubMed]

39. Zhang, J.; Wu, G.Y.; Zhang, J.P. China's inter-provincial material capital stock estimation: 1952-2000. Econ. Res. 2004, 39, 35-44.

40. Sun, Z.; Jia, S.F.; Yan, J.B. Research on background matching status of land and water resources in China. J. Nat. Resources. 2018, 33, 2057-2066.

41. Zhong, K.Y. Does the digital finance revolution validate the Environmental Kuznets Curve? Empirical findings from China. PLoS ONE 2022, 17, 119. [CrossRef]

42. Wang, Y.D.; Zuo, Q.T.; Liu, H. Analysis of matching characteristics and balance of water and land resources in Henan Province People's Yellow River 2018, 40, 55-59, 64.

43. Riquelme, F.J.; Ramos, A.B. Land and water use management in vine growing by using geographic information systems in Castilla-La Mancha, Spain. Agric. Water Manag. 2005, 77, 1-95. [CrossRef]

44. Yang, Y.; Wu, C.; Luo, G.H. Research on the "growth damping" of China's land and water resources on the economy. Econ. Geogr. 2007, 12, 529-532, 537.

45. Huang, X.H.; Lu, Q.; Wang, L. Research on Capital Endowment, Ecological Cognition and Farmers' Water and land Conservation Technology Adoption Behavior-Based on the Regulatory Effect of Ecological Compensation Policies. Agric. Technol. Econ. 2020, $39,33-44$.

46. Zhong, K.Y.; Wang, Y.F.; Pei, J.M.; Tang, S.M.; Han, Z.L. Super Efficiency SBM-DEA and Neural Network for Performance Evaluation. Inf. Process. Manag. 2021, 58, 102728. [CrossRef]

47. Thomas, J.; Joseph, S.; Thrivikramji, K.P. Assessment of landerosion in a tropical mountain river basin of the southern Western Ghats, India using RUSLE and GIS. Geosci. Front. 2018, 9, 893-906. [CrossRef]

48. Brown, L.R.; Brian, H. China's water shortage could shake world food security. World Watch 1998, 11, 10-18.

49. López-Moreno, J.I.; Morán-Tejeda, E.; Vicente Serrano, S.M. Impact of climate evolutionand land use changes on water yield in the Ebro basin. Hydrol. Earth Syst. 2011, 15, 311-322. [CrossRef]

50. Stefan, B.; Janez, P.; Heinz, S. Multi-Scale Governance of Sustainable Natural Resource Use-Challenges and Opportunities for Monitoring and Institutional Development at the National and Global Level. Sustainability 2016, 8, 778. 